\title{
Do Firms Decouple Corporate Governance Policy and Practice?
}

\author{
Nasha Ananchotikul \\ University of California, Berkeley \\ Roy Kouwenberg* \\ Erasmus University Rotterdam and Mahidol University \\ Visit Phunnarungsi \\ Mahidol University
}

This version: January 12, 2008

\begin{abstract}
An interesting open question is whether the adoption of formal good corporate governance policies by listed firms is mainly symbolic, or indicative of substantive implementation of good governance practices. In this paper we use data on Thai listed firms to test whether firms with higher levels of good governance policy adoption are less likely to violate listing rules and laws put in place to protect shareholders. Our results suggest that Thai firms on average substantively, as opposed to symbolically, implement recommended governance policies, as violations occur less frequently among firms with higher levels of formal good governance policy adoption. However, we do find that the negative relation between formal policy adoption and subsequent violations is significantly weaker among smaller firms, less profitable firms and "talk-only" firms that issue policy statements about good governance while lagging in the adoption of policies related to shareholders rights and the Board of Directors.
\end{abstract}

Key words: Corporate governance; violations; fraud; symbolic implementation; Thailand JEL classification: G3, G38, K42

*Corresponding author: Erasmus University Rotterdam, Faculty of Economics, Finance Department, P.O. Box 1738, 3000 DR, Rotterdam, Netherlands and Mahidol University, College of Management, 69 Vipawadee Rangsit Road, 10400, Bangkok, Thailand. Email: kouwenberg@few.eur.nl and cmroy@mahidol.ac.th. Financial support from a CMMU faculty research grant is gratefully acknowledged. We would like to thank Barry Eichengreen, Nareerat Taechapiroontong, Thanaphol Virasa and Kelvin Willoughby for their suggestions and comments. All errors are ours. 


\section{Introduction}

In the last decades most developed and many developing countries have issued an official corporate governance code or good governance guidelines. ${ }^{1}$ Listed firms in these countries are generally required to disclose their voluntary compliance with the good governance principles. Outsiders -including minority shareholders and regulators - have to rely mostly on this disclosed information and annual reports to assess a firm's corporate governance quality and typically face a severe asymmetric information problem. This raises an interesting question: is adoption of formal good governance policies always associated with substantive good governance practices? In other words, is the adoption of formal good governance policies more than windowdressing to improve the firm's external image? A series of corporate meltdowns due to governance misconducts such as in the cases of Enron, WorldCom and Tyco provides notorious examples of firms that adopted formal good corporate governance policies while failing to live up to the intent of these policies.

Some might argue against symbolic implementation of governance policies on the ground that many empirical studies have found a positive relationship between corporate governance mechanisms and firm value (Klapper and Love, 2004, Durnev and Kim, 2005, Black et al., 2006). The most straightforward explanation is that implementation of good governance principles by the firm helps to create more value for shareholders, leading to a higher value of the firm. However, managers may also adopt good policies only as a signal to shareholders that they will not expropriate the firm's assets, and it might be this signal to investors, not the substantive implementation of good governance practices, that leads to an increase in the market value of the firm. ${ }^{2}$ Investors might process all available information efficiently, but this does not resolve the

\footnotetext{
1 The ECGI provides on its website comprehensive and up-to-date database on official corporate governance codes from 59 countries, including 29 developing countries. The ECGI's website is at http://www.ecgi.org/index.htm.

2 For a sample of 859 companies in 27 countries, Durnev and Kim (2005) find that better corporate governance, i.e. higher scores on the Credit Lyonnais Securities Asia (CLSA) corporate governance index or the S\&P disclosure index, is associated with higher Tobin's Q. Klapper and Love (2004) also rely on the
} 
fundamental asymmetric information problem regarding the substantive implementation of good governance policies. Again, the unforeseen meltdowns of Enron, WorldCom, and their likes around the world (Parmalat, Ahold, for example) illustrate the extent of the problem.

This paper aims to address the question whether adoption of formal good governance policies is a credible signal of the firm's intent to substantively implement the policies, by tracking subsequent violations of rules and regulations put in place to protect shareholders. Very little has been written on the relation between the adoption of formal good governance policies and subsequent governance practices. Closest to our paper is a study by Chen et al. (2006) that examines the effect of ownership structure and boardroom characteristics on corporate financial fraud in China. Using data on enforcement actions of the Chinese Securities Regulatory Commission, they find that a higher proportion of outside directors is associated with a lower probability of fraud. While Chen et al. (2006) investigate whether various governance mechanisms can help to explain fraud, our paper studies violations to see whether a large sample of Thai firms that voluntarily adopted formal governance policies really implemented them.

We develop hypotheses predicting which firms are more likely to engage in symbolic adoption of corporate governance policies, following related work in this area by Westphal and Zajac (1994, 1998, 2001). Westphal and Zajac (1994, 2001) show that many large U.S. firms engage in symbolic management by announcing long-term incentive plans and stock repurchase plans, without ever implementing these plans subsequently. Westphal and Zajac (1994) draw upon the literature on impression management and institutional theory to explain and predict which firms are most likely to decouple policy and practice. They argue that high CEO power, low firm performance and late adoption are key factors driving symbolic behavior. We adapt parts of Westphal and Zajac's framework to the Thai context. Unlike in the U.S., the major

CLSA index to examine corporate governance of 374 large firms in 145 emerging markets. They also find support for this relationship. Black et al. (2006) develop a system of simultaneous equations and apply twostage and three-stage least squares to cope with endogeneity problems. Their results also support the hypothesis of a positive relationship between corporate governance and Tobin's Q. 
agency conflict in Thailand arises from highly concentrated ownership of firms. As concentrated ownership is the norm in many stock markets around the world, both developed and developing, our work addresses a relevant gap in the literature in our opinion.

Our empirical analysis uses data on listed firms in Thailand. The Stock Exchange of Thailand (SET) introduced a voluntary corporate governance code for listed companies in March 2002 consisting of 15 principles of good governance, similar to existing codes in developed markets (e.g. the U.K). ${ }^{3}$ The code addresses the protection of rights of minority shareholders and other stakeholders, the importance of independent directors and the disclosure of potential conflicts of interest, among other things. Listed firms must disclose their voluntary compliance with good governance principles yearly in their annual reports and registration statements on a “comply-or-explain" basis. In 2003, the Corporate Governance Center of the SET conducted a study that measured the adoption of the governance code based on firms' disclosed information for the fiscal year 2002, resulting in a composite code adoption score for 333 listed companies.

To test our main hypothesis that the adoption of governance policies reduces the likelihood of subsequent misbehavior by firms, we develop an objective, outcome-based measure of misbehavior, by focusing on violations of listing rules and regulations put in place to protect shareholders. Thai listed firms are monitored and regulated by the stock exchange and the Thai Security and Exchange Committee (SEC). We use publicly available information on violations announced by both the SET and SEC, including failure to disclose information about related party connections, failure to disclose other material information, forced rectifications of financial statements, and violations of the regulations relating to market manipulation and tender offers. Further, we include data on warnings issued by the exchange when an auditor expresses an adverse opinion, a disclaimer of opinion, or a qualified opinion about a listed firm's financial statements.

\footnotetext{
${ }^{3}$ Prior to the introduction of the 15 principles, in 1998 the Stock Exchange of Thailand (SET) required all listed companies to establish an audit committee. Further, in 1998 the SET also issued a code of best practices for board members of listed companies.
} 
We are aware that our measure of corporate misbehavior is only a partial measure, as many violations of the rules and other forms of bad governance behavior might not be detected by the regulators. We mitigate this problem by estimating econometric models that are designed to deal with the problem of partial observability (see Poirier, 1980 and Feinstein, 1990). Various model specifications are also tested to check robustness of the results.

Overall, we find that the relationship between adoption of good governance policies and subsequent violations of rules is negative, indicating substantive implementation of governance policies by a typical Thai firm. However, in line with our hypotheses, the relation is significantly less negative among firms with poor prior performance, smaller firms and among "talk only" firms. ${ }^{4}$ The presence of a controlling shareholder is associated with lower corporate governance quality, while the type of the controlling shareholder such as family business group and the Thai government does not affect the extent of symbolic or substantive implementation.

The paper is organized as follows. Section 2 reviews the literature on symbolic adoption of policies versus substantive implementation, as well as the literature on fraud committed by listed firms and earnings management. Section 3 develops hypotheses about the decoupling of formal governance policies and substantive practices at Thai firms, building on prior research by Westphal and Zajac (1994). Section 4 introduces our measures of formal policy adoption and violations of rules and regulations. Section 5 presents the econometric models and explanatory variables, while Section 6 discusses the estimation results. Section 7 concludes the paper.

\section{Literature Review: Symbolic Adoption versus Substantive}

\section{Implementation of Corporate Governance Policies}

In this section, we review prior research on the symbolic versus substantive adoption of corporate governance policies. We first focus on the interesting work of Westphal and Zajac (1994, 2001),

\footnotetext{
${ }^{4}$ We define "talk only" firms as firms scoring high on policy statements about good governance and ethics, but scoring low on adoption of formal policies relating to shareholder rights and the Board of Directors.
} 
who document and explain widespread symbolic adoption of long-term incentive plans and stock repurchase programs by large U.S. firms. We also discuss the accounting-fraud literature: the evidence on the ineffectiveness of various governance mechanisms in preventing fraud from this literature also points to the possibility that firms' adoption of governance policies might be mostly symbolic.

\subsection{Evidence from the Implementation of Long-Term Incentive Plans}

Westphal and Zajac (1994) study the adoption and implementation of long-term incentive plans (LTIPs) by U.S. firms over the period 1972 through 1990. Long-term incentive plans typically involve stock options, stock appreciation rights, restricted stocks and performance plans for the CEO and other top managers. LTIPs can be considered as a governance mechanism, as in theory they mitigate the agency problem between managers and shareholders by tying part of management compensation to the firm's stock price. Surprisingly, Westphal and Zajac (1994) estimate that at least 21 percent (and up to 45 percent) of the 570 U.S. firms in their sample who adopted long-term incentive plans did not grant any options, stocks or other units to management in the following years. Hence, in these cases the adoption of LTIPs by the firm's Board is mainly symbolic, as it is never followed up by actual implementation: this is referred to as decoupling of policy from practice.

Westphal and Zajac (1994) draw upon the literature about impression management and institutional theory to explain why firms decouple the adoption and implementation of LTIPs, and under what circumstances. First, decoupling increases the legitimacy of powerful CEO's, while minimizing the risk of their compensation contracts. Second, decoupling can arise from the need to manage stakeholder's impressions in the face of poor firm performance. Third, decoupling can arise as a reaction to the increased legitimization and institutionalization of LTIPs by firms who do not actually want to alter their existing compensation structure. 
Westphal and Zajac (1994) formulate and test the following statistical hypotheses: (i) the greater the CEO's influence over the Board, the greater the likelihood that a firm will adopt an LTIP, but the lower the likelihood that the firm will actually use the LTIP after adoption; (ii) the lower a firm's performance, the greater likelihood that a firm will adopt, but not necessarily use, LTIPs; (iii) the later the date of LTIP adoption, the smaller the likelihood and magnitude of subsequent grants made under the plan. The empirical evidence in Westphal and Zajac (1994) supports all three hypotheses.

\subsection{Evidence from the Implementation of Stock Repurchase Programs}

Westphal and Zajac (2001) further investigate decoupling of policy from practice by focusing on stock repurchase programs. Share buyback plans redistribute part of a firm's free cash flows to investors and could therefore make it more difficult for managers to waste company resources (e.g., on excessive perks and empire-building). Further, the initiation of a share buyback program might also signal the firm's bullishness about its own future. Westphal and Zajac (2001) argue that firms might also symbolically announce a stock repurchase program - without implementing it - to alleviate or avoid external pressure for more substantial changes in corporate governance.

As a measure of stock repurchase plan implementation, Westphal and Zajac (2001) divide the number of shares repurchased in a given year as part of an outstanding plan by the number of shares reserved under the plan for repurchase in that year. On average, the ratio equals 0.09 , indicating that many repurchase plans are either not, or only partially, implemented. Netter and Mitchell (1989) provide similar evidence: the majority of NYSE firms who announced a share buyback program after the 1987 crash - in an effort to support the market - did not subsequently implement the plan.

Following Westphal and Zajac (1994), one of the main hypotheses in Westphal and Zajac (2001) is that there is negative relation between CEO power and the level of repurchase plan implementation. The empirical results support this hypothesis: the stronger CEO power, the lower 
the share buyback implementation ratio. The other hypotheses in Westphal and Zajac (2001) mainly consider network effects: the more ties a firm has to other firms that have decoupled share repurchase plans or LTIPs, through directors that serve on multiple Boards, the lower the extent of share repurchase plan implementation. The data support the hypotheses on network effects. Another interesting finding is that institutional ownership significantly lowers the likelihood of repurchase plan implementation, suggesting that firms respond to institutional investor pressure with symbolic action.

\subsection{Evidence from the Literature on Fraud and Earnings Management}

Empirical evidence on the effect of widely used governance mechanisms - including outside directors, audit committees, and institutional shareholders - in monitoring management and preventing fraud is mixed. Some studies document a negative relationship between good governance mechanisms and fraud (Beasley, 1996, Chen et al., 2006), and earnings management (Dechow et al., 1996). Chen et al. (2006) examine the effect of board characteristics on corporate financial fraud in China and conclude that outside directors can help to deter fraud, while Beasley (1996) reports similar results for financial statement fraud among U.S. firms.

On the other hand, several other studies find that the presence of governance mechanisms does not seem to deter corporate misbehavior. For example, Uzun et al. (2004) find that board characteristics such as size of the board, frequency of meetings, and CEO/Chairman duality are not associated with fewer fraud occurrences. Agrawal and Chadha (2005) and Park and Shin (2004) find that outside directors do not reduce earnings management; only when there is an independent director with financial expertise that they find that the probability of earnings management is lower. ${ }^{5}$ They also document that other key governance characteristics including

\footnotetext{
${ }^{5}$ Earnings management is not necessarily illegal; it does not violate Generally Accepted Accounting Principles (GAAP). However, managers engaging in earnings management are regarded as being opportunistic and untruthful to shareholders. The sources of earnings manipulations within GAAP include the choice of accounting methods, the application of accounting methods, and the timing of asset acquisitions and dispositions.
} 
audit committees, the provision of non-audit services by outside directors, and the average tenure of outside directors, are unrelated to the probability of accounting manipulations.

The apparently mixed results of existing work on the effectiveness of governance mechanisms calls for more research on this topic. Park and Shin (2004) suggests in a study of Canadian firms that the ineffectiveness of governance mechanisms may be due to the highly concentrated ownership and underdeveloped market for outside directors in Canada. In this paper, we argue that, beside policy ineffectiveness, decoupling of formal policy from practice may be another plausible reason why several studies did not detect positive effects of common governance mechanisms on fraud deterrence. For example, a firm might nominate a director that is formally independent, but in practice connected to management or controlling shareholders. Audit committees can be undermined by withholding relevant information, and other tactics (such as providing unintelligible financial statements minutes before the start of a meeting). Whether our presupposition regarding symbolic adoption of good governance policies is correct is subject to the empirical evidence in this paper.

\subsection{Evidence from Other Literature}

Other evidence on the decoupling of policy and practice can be found in Stevens et al. (2005) on the implementation of ethics codes, and Yeung and Mok (2005) and Christmann and Taylor (2006) on the implementation of standards by Chinese ISO certified firms. Stevens et al. (2005) use survey questions to measure to what extent senior financial executives integrate their company's ethics code into their strategic decision making. Stevens et al. (2005) find that substantial implementation of an ethics code is more likely in response to pressure from "market stakeholders", including customers, suppliers, banks, competing firms and shareholders, while pressure from "non-market stakeholders" such as regulatory agencies, government bodies and special interest groups has less impact on implementation. 


\section{Hypothesis Development}

\subsection{Symbolic versus Substantive Implementation of CG within the Thai Context}

The work of Westphal and Zajac and others on decoupling provides an interesting perspective on the adoption of good governance policies by Thai firms. Initiatives to improve corporate governance were mainly introduced by the Thai government and Thai regulatory bodies as a reaction to the Asian crisis, driven by recommendations from international organizations such as the IMF and the World Bank. As most of these good governance initiatives did not emanate from Thai firms themselves, a relevant question is to what extent Thai firms support these governance reforms, and whether they implement good governance policies substantially or only adopt them symbolically.

Westphal and Zajac find that a considerable number of large U.S. firms symbolically adopt and announce long-term incentive plans for top management, as well as share repurchase programs - both can be considered as mechanisms to reduce agency conflicts between management and shareholders - without substantially implementing these plans. The context in which Thai firms operate differs from the U.S. context in a number of important ways. First, concentrated ownership is the norm in the Thai market: a majority of Thai firms are owned by founding families. Second, lack of pressure from non-family shareholders: there is no active market for corporate control of Thai firms, and there are no large powerful domestic institutional shareholders pressing for governance reforms. ${ }^{6}$ Third, cost of implementation: in a developing country like Thailand, weak rule of law and lack of human resources may elevate the cost of good governance implementation to be well above that incurred by firms in mature countries. We will now adopt the hypotheses tested by Westphal and Zajac (1994) to these three distinguishing features of the Thai context.

\footnotetext{
${ }^{6}$ Large foreign institutional shareholders might be the only exception, but their influence is limited by restrictive caps on foreign ownership. See Ananchotikul (2007) for a detailed study of the impact of foreign investment on the corporate governance of Thai listed firms.
} 


\subsection{Hypotheses}

Our aim is test whether voluntary adoption of the formal good governance policies recommended by the Thai code is a purely symbolic act or indicative of substantive implementation of good governance practices, by investigating the relation with subsequent violations of rules and regulations put in place to protect shareholders. As a working hypothesis we will assume that Thai firms decouple policy and practice, and therefore the extent of formal good governance policy adoption will be either unrelated to subsequent violations of rules and regulations, or positively related.

Hypothesis H1: Measures of the extent of formal good governance policy adoption have a non-negative relation with subsequent violations of rules and regulations.

If we reject $\mathrm{H} 1$ and the relationship between code adoption scores and subsequent violations is negative, we conclude that adoption of formal good governance policies by Thai firms is not purely symbolic, but indicative of substantive implementation of good governance practices.

We will now refine hypothesis $\mathrm{H} 1$ and distinguish various groups of firms that are expected to engage in decoupling to a larger or smaller extent than others. These hypotheses will be tested by including various interaction effects with the policy adoption score in the regression of violations on good governance policy adoption scores.

The work of Stevens et al. (2005) indicates that firms are more likely to substantively implement good governance practices when important stakeholders, such as suppliers, customers and shareholders, attach value to this. Within the Thai context, good governance initiatives are 
mainly driven by the Thai government. For this reason we expect state-owned companies to adopt good governance policies more readily, as well as implement them substantively. ${ }^{7}$

Hypothesis H2a: State-owned firms are more likely to adopt formal good governance policies.

Hypothesis $\mathrm{H} 2 \mathrm{~b}$ : The relation between the adoption of formal good governance policies and subsequent violations is negative among state-owned firms.

One of the main hypotheses in Westphal and Zajac (1994) is that firms with powerful executives are more likely to decouple policy from practice. Westphal and Zajac (1994) focus mainly on CEO power, i.e. the agency conflict between top management and shareholders. In Thailand the fundamental agency problem is not between managers and owners-as most firms have highly concentrated ownership_but rather between minority shareholders and controlling shareholders. ${ }^{8,9}$ Similar to powerful CEO's, controlling shareholders might gain reputational benefits from engaging in symbolic adoption of good governance policies, while avoiding the potential costs of these policies by not implementing them substantively. Furthermore, minority shareholders at this type of firm may not have sufficient clout to push for substantive implementation. Examples of symbolic good governance policies include: issuing pro forma statements about good governance and ethics; improving official procedures related to shareholder meetings and voting rights (relatively painless for a firm with concentrated

\footnotetext{
${ }^{7}$ In this paper, a state-owned firm is defined as a firm that has the Thai government, the Royal family or Crown Property Bureau as the largest shareholder holding a block of $25 \%$ or more shares.

${ }^{8}$ We define a "controlling shareholder" as the largest shareholder (an individual or a group of family members) holding more than 25 percent of the firm's outstanding shares directly or indirectly. As noted in Ananchotikul (2007), under the Public Limited Companies Act, at or above 25 percent shareholdings, a shareholder has sufficient voting rights to do the following: 1) nullify any corporate decisions, 2) demand to inspect the business operation and the financial condition of the company, as well as the conduct of the board, 3) call an extraordinary general meetings at any time, and 4) submit a notion to the court demanding for the dissolution of a company if s/he believes that further company operations will bring only losses, and that the company has no chance of recovery. Since deviation from one-share-one-vote rule is not allowed in Thailand, voting rights are proportional to the number of shares owned by a shareholder.

${ }^{9}$ This definition covers business groups, corporations, individual investors, including foreign investors, as a controlling shareholder. It does not cover the government, unless stated otherwise.
} 
ownership); appointing "friendly" (i.e. connected) directors who are independent according to the official definition.

On the other hand, widely-held firms may be less likely to explicitly improve shareholder rights because, without concentrated ownership, the risk of transferring power to outsiders is higher. Further, for CEO's of widely-held firms it might be more difficult to nominate a "friendly" independent director who is also well-received by a majority of the minority shareholders, since a small group of shareholders can in principle oppose the appointment if they doubt the CEO's intention. So, when a widely-held firm does decide to voluntarily improve shareholder rights or to appoint independent directors, substantive change in governance practices seems more likely than among firms with a controlling shareholder.

For all of the reasons stated above, it might be easier for non-state-owned firms with a controlling shareholder to comply with governance policies than widely-held firms, but their policy adoption may only be symbolic. This gives rise to the following hypotheses:

Hypothesis H3a: Non-state-owned firms with a controlling shareholder are more likely to adopt formal good governance policies.

Hypothesis H3b: The extent to which a widely-held firm adopts formal good governance policies predicts subsequent violations of rules negatively, while the relation is nonnegative among non-state-owned firms with a controlling shareholder.

According to Westphal and Zajac (1994), another rationale for firms to engage in symbolic action is in response to poor performance. They posit that, from an impression management point of view, poor management and/or financial performance threatens the credibility of board members as competent guardians of stakeholder interests. In order to alleviate this difficult situation, the Board may decide to at least "give the appearance of efficacy" by symbolically affirming and tightening their control over management. Substantive implementation appears less likely, as 
Board members are not involved in the daily management of the firm. Further, poor financial performance might also reduce the resources available for substantive implementation of policies.

Hypothesis H4a: Poor performance increases the likelihood that a firm adopts formal good governance policies.

Hypothesis H4b: The relation between adoption of good governance policies and subsequent violations of rules is influenced negatively by prior performance.

Based on institutional theory, Westphal and Zajac (1994) argue that late adopters of policies are less likely to implement them substantively, as policies become more institutionalized and widespread among organizations. Early adopters, on the other hand, are more likely to be driven by the potential technical and economic benefits of the policies, and therefore more likely to implement the policies substantively. Within the Thai context, firms who adopted formal corporate governance policies before the introduction of the Thai code by SET in 2002 can be considered early adopters. Our measure of early adoption is defined more precisely in the measurement section.

Hypothesis H5: The relation between adoption of good governance policies and subsequent violations of rules is influenced negatively by early adoption.

As discussed shortly below, our measures of formal corporate governance policy adoption is divided into three categories: (i) statements issued by firms about good governance, ethics and corporate mission; (ii) formal policies related to shareholder rights; (iii) board structure and independence. As the first category is purely based on written statements, the ease of engaging in purely symbolic actions seems greater. We single out firms that score relatively high in the first category, but rather low in the second or the third category and label them "talk only" firms. We 
expect that firms in the "talk only" group are less likely to substantively implement formal good governance policies than other firms:

Hypothesis H6: The relation between adoption of good governance policies and subsequent violations of rules is influenced positively by a "talk only" indicator variable.

Lastly, the size of a firm may be another factor affecting the firm's decision to adopt corporate governance policies, both symbolically and substantively. Large firms may be more likely to adopt and carry out substantive implementation of governance policy because the associated cost, as a share of total expenses or total net profits, may be substantially lower than for small firms.

Hypothesis H7a: Large firms are more likely to adopt formal good governance policies than small firms.

Hypothesis H7b: The relation between adoption of good governance policies and subsequent violations of rules is influenced negatively by firm size.

\section{Measurement of Variables}

\subsection{Measurement of Formal Corporate Governance Policy Adoption}

In 2003 the SET used information about corporate governance disclosed by firms for the accounting year 2002 to construct a measure of listed firms' adoption of the various good governance policies recommended by the Thai Code. The measure is based on an assessment of: (i) written claims issued by the firm about its adherence to good governance principles (e.g. the firm writes in its annual report or on its website that it adheres to principles of good governance); (ii) formal policies related to the good governance principles that can be objectively verified (e.g. the firm has procedures facilitating voting by proxy, and the Board has established a remuneration committee); (iii) disclosure of information related to good governance or relevant for stakeholders (e.g. the remuneration of each director is disclosed in the annual report). 
The governance index constructed by SET is a weighted average of 15 subscores, one for each of the 15 principles of good governance described in the Thai code. We have assessed each of these 15 measures and checked carefully whether they are solely based on written claims by the firm about the adoption of good governance policies, and/or factual information about the adoption of formal good governance policies by the firm, without containing additional information about the substantive implementation of these policies. The reason we want to exclude potential information about substantive implementation of good governance practices is that in our research design adoption of formal governance policies is used as a predictor of subsequent violations, our outcome-based measure of substantive implementation. Hence, we want to make sure that the adoption of formal policies measure does not accidentally contain some information about substantive implementation as well.

Below is list of nine good governance principles from the Thai Code that we deemed relevant and met our stated criteria, divided in the three main groups: A. Policy Statements, B. Shareholder Rights, and C. Board Structure and Independence. ${ }^{10}$ Below each principle we list the information used by the Thai exchange to assess the adoption by listed firms in 2002 and assign sub-scores. For each of the three groups, we indicate briefly how firms might be able to decouple policy and practice.

\section{A. Policy Statements:}

Principle 1, "Policy on Corporate Governance":

- The company has a written corporate governance policy.

Principle 7: "Business Ethics"

- The Board of Directors provides a code of ethics or statement of business conduct for all directors and employees.

Principle 5: "Leadership and Vision"

\footnotetext{
${ }^{10}$ Appendix 1 lists the good governance principles that we choose not to use for our study, with motivation.
} 
- The company provides information on its corporate vision / mission.

Potential for symbolic adoption: clearly, firms can choose to adopt these policies only symbolically, without making any substantial changes in firm governance.

\section{B. Formal Policies Related to Shareholder Rights:}

Principle 4: Shareholders: Rights and Equitable Treatment

- Implementation of the "one-share-one-vote" principle.

- Procedures facilitating voting through proxy.

Principle 2: "Shareholders' Meeting"

- Sending out the notice of a shareholder meeting well in advance.

- Providing sufficient information on each agenda item of the shareholder meeting, including names and sufficient background information when the appointment of a director or auditor is proposed.

- Encouraging shareholders to express their opinion and ask questions during shareholder meetings.

Potential for symbolic adoption: given the prevalence of large controlling shareholders in Thailand, the lack of a market for corporate control, limits on foreign ownership in most industries, and the absence of large domestic institutional investors who would represent active shareholders, the majority of listed firms can adopt these policies without effectively giving more influence to shareholders.

\section{Board Structure and Independence:}

Principle 8: "Balance of Power in the Board"

- Proportion of independent directors on the Board.

- Number of independent directors on the Board.

- Firm provides its own definition of an independent director. 
Principle 9: "Segregation of Positions"

- The titles and authority of the Board's Chairman and head of the management team are clearly separated.

- The Chairman of the Board is independent.

Principle 12: "Committees"

- The firm has an audit committee, and a remuneration committee.

- The audit committee has at least three members and at least of one of the members has knowledge of, or experience in, accounting and/or finance.

- The majority of members of the remuneration committee are non-executive directors and the committee's chairman is independent.

Principle 14: "Directors' Reporting"

- The Board of Directors provides a statement of its responsibilities concerning the company's financial reports, presented alongside the auditor report and the audit committee report.

- The Director's report is signed by all Board members.

Potential for symbolic adoption: given the high ownership concentration prevalent in the Thai market, controlling shareholders typically have great influence on the selection and appointment of independent board members. The Thai cultural context, high on power distance, collectivism and uncertainty avoidance, also reduces the likelihood that independent directors will confront or correct management when they suspect inappropriate actions. Overall, there appears to be some scope for decoupling.

We create a formal governance policy adoption score for each of the three categories above by equally weighting the sub-scores given to the various principles. The three cross-sectional policy adoption indices are denoted by CG Policy, CG Shareholders and CG Board. Finally, we create 
our overall measure of adoption of formal good governance policies by firms, CG Total, as an equally-weighted average of $C G$ Policy, $C G$ Shareholders and $C G$ Board.

\subsection{Measurement of Violations of Rules and Regulations}

We now describe our measure of violations of the principles of good governance by the firm and its controlling shareholders, to be used as an indirect, outcome-based, measure of substantive implementation of good governance practices.

Thai listed companies fall under the supervision of the exchange (SET) and the market regulator (SEC). The Stock Exchange of Thailand supervises the dissemination of information by listed companies; it can impose fines, and suspend trading, when listed firms fail to submit financial reports or any information which is likely to have a significant effect on the stock price. Further, SET monitors the trading of stocks for signs of insider trading and market manipulation. SET issues a variety of "trading sign" announcements to notify investors of information dissemination problems at listed companies, and/or other unusual situations that could potentially affect a security's price.

The first sign, "NP (Notice Pending)", is issued to indicate that the SET is waiting for additional information or clarification from the company, or when a listed firm has failed to submit its financial statements within the deadline. The second sign, "H (Halt)" is issued when trading in the security is halted for one trading session, due to critical changes or events affecting the company during trading hours, requiring further clarification to the SET. The third sign, "SP (Trading Suspension)", indicates that trade in a security has been suspended for more than one trading session, typically due to prolonged failure of a listed firm to comply with disclosure regulations. Once the company resolves the issue identified by SET, the trading sign is lifted, and in the case of a trading halt or suspension, trading is resumed as well.

We collect data on trading signs imposed by the SET for the period 1990-2006 from the SETSMART database (SET Market Analysis and Reporting Tool). The data includes the date the 
trading sign is imposed, the listed firm involved and the announcement of SET describing the reason for issuing a trading sign. We have analyzed all SET trading sign announcements, filtered out ones not related to good governance and then categorized them in the following groups:

1. Violation of rules regarding the disclosure of related party transactions and other material information:

- The firm is forced by the SET to disclose information about a related parted transaction, or other material information, to the public.

2. Violated of rules and procedures regarding financial statements:

- The financial statement submitted by the firm contains errors, or does not comply with generally accepted accounting standards.

- The financial statements were not submitted by the deadline, or not submitted following the relevant procedures.

3. Warnings issued when the firm's auditor does not issue an unqualified opinion:

- The firm's auditor issues a qualified opinion, an adverse opinion, or a disclaimer of opinion about the firm's financial statement.

4. Violation of the rules regarding tender offers:

- The firm fails to report that its shareholding of another public company passes a multiple of $5 \%$ of the outstanding shares.

- The firm does not make a tender offer when required.

Apart from the stock exchange, the supervision of listed companies is the responsibility of the Thai Securities and Exchange Committee (SEC). The SEC investigates possible offences of the securities law and if it deems that a serious violation has occurred, the SEC will file a criminal complaint with the Economic Crime Investigation Division of the Thai Police for prosecution. However, certain less grave offences can be fined directly by the SEC's Settlement 
Committee. We collect data from the SEC's website on fines imposed and criminal complaints filed during the period 1999-2006. ${ }^{11}$ The types of violations include expropriation, falsification of financial statements, insider trading and market manipulation. The website provides the name of the offender, the specific law and the section of the law that were violated, a short description of the accusation and, if available, the fine imposed or the outcome of the criminal justice process. We examine each case to verify whether the offenders identified by SEC were employees, Board members or controlling shareholders of a listed company in our sample at the time of the violation, and if this is the case, we link the violation to the listed company and record the year the offense took place. ${ }^{12}$

Table 1 provides an overview of all the SEC and SET information that we use to construct our measure of violations of the principles of good governance, as well as the number of violations involved. Please note that all violations covered in Table 1 are clearly at odds with good corporate governance practices, either involving fraud or failure to disseminate relevant information to shareholders and the public at large. We classify the various violations into three groups based on their severity, see Table 1, as follows: (1) Severe violation of good governance principles; (2) Medium, i.e. a violation that is neither severe nor minor; (3) Minor violation.

For our research we are mainly interested in the total number of violations committed by the firm in the period 2003-2006-the period after the SET governance scores were collected. As a small number of firms were delisted before the end of 2006, we adjust the number of violations for the length of period that a stock was listed, creating the following measure: the average number of violations per year listed in the period 2003-2006. To take into account the difference in severity among the various violations, we also calculate a severity-weighted measure of the violations measure, with a weight of $1 / 6$ for minor violations, $2 / 6$ for medium violations and $3 / 6$

\footnotetext{
${ }^{11}$ Data on SEC violations is available from 1999 onwards. See: http://www.sec.or.th/enforcement/Content_0000000392.jsp?categoryID=CAT0000278\&lang=en

${ }^{12} \mathrm{We}$ also checked for potential overlap with the trading signs imposed by the exchange. In our sample, there are only two cases where a violation received both a SET trading sign and a SEC fine and/or criminal complaint; both cased involved companies failing to make a tender offer.
} 
for severe violations. The choice of the weights has very little impact on the overall measure, as the occurrence of medium and severe violations is positively correlated $(+0.55)$, and minor violations do not occur more frequently than other two types. We will use these two variables as the dependent variables in our empirical analyses. As control variables in our regression models we will also use similar measures for the historical period 1990-2002.

Apart from the total number of violations, Table 1 also shows the average number of violations per year in the period 1990-2002 and 2003-2006. Comparing the two periods, we observe a remarkable shift from more serious fraud cases in the period 1990-2002 towards “cooking the books", i.e. incorrect financial statements, in the period 2003-2006. The underlying reason is probably the relatively unchecked rapid development of the Thai stock market before the 1997 crisis, marred by corruption and lack of good governance, followed by a tightening of the regulatory environment, improved standards of accounting and auditing, and an increased focus on governance. Although the type of violations detected and/or committed might have changed, the frequency of violations is remarkably stable: the average number of violations per firm per year listed is 0.182 in 1990-2002 versus 0.181 in 2003-2006 (correlation: +0.32 ).

\subsection{Measurement of Early Adoption}

In Hypothesis 5, we posit that early adopters of formal corporate governance policies are more likely to substantively implement them, resulting in lower probability of violations. To determine which firms were early adopters, we employ the firm-level corporate governance data on Thai listed firms collected in 2000 by Ananchotikul (2007). Since in 2000 Thai listed firms were not yet required to disclose much information about governance, we have to choose some specific governance items as proxies.

Among the mechanisms with information available in 2000, we view board independence and the absence of the Chairman-and-CEO duality as clear signals that a firm is aware of, and 
adopts, good governance policies. ${ }^{13}$ Thus, we define a firm as an early adopter if in 2000 it satisfied both of the following criteria: (i) independent directors comprised at least 25 percent of the Board of Directors; (ii) Chairman and CEO separation-the Chairman and the CEO were not the same person. There are 77 firms in our sample that satisfy the former criterion in 2000, and 65 that satisfy the latter. Only 29 firms possessed both governance attributes in 2000 and are defined as early adopters.

\subsection{Definition of "Talk Only" Firms}

Firms that score high on policy statements concerning good governance, business ethics and corporate mission, but low on formal policies affecting shareholder rights, board structure and board independence are dubbed "talk only" firms. To test Hypothesis 6, we create a "talk only" dummy variable: it equals 1 if a firm has a $C G$ Policy score among the top 33 percent, but either a $C G$ Shareholders score or a CG Board score in the bottom 33 percent; the dummy is 0 otherwise. In total 43 firms out of 333 - 12 percent - are identified as "talk only".

\section{Econometric Models}

The dependent variable of interest for our study is the average number of violations per year committed by listed firms during the period 2003-2006, denoted by $F_{i}$ for $\mathrm{i}=1,2, \ldots, I$. As 239 out of 333 firms in the sample were not found by the regulators to violate any rules during this period, the distribution of the dependent variable has a relatively large probability mass at zero (see Figure 1A), invalidating ordinary least squares regression models. To take into account the left-censoring in the data, we can estimate a standard Tobit model. Let $F_{i}{ }_{i}$ be a latent variable that measures the firm's propensity to violate the rules. The Tobit model is:

\footnotetext{
${ }^{13}$ An audit committee is another important mechanism, but all listed Thai firms were required to establish an audit committed starting from 1999.
} 
(1) $F_{i}^{*}=X_{1 i} \beta_{1}+\varepsilon_{i}$

$$
\begin{array}{ll}
F_{i}=F^{*}, & \text { if } F^{*}{ }_{i}>0, \\
F_{i}=0, & \text { if } F^{*}{ }_{i} \leq 0,
\end{array}
$$

where $X_{1 i}$ is a $\left(1 \times k_{1}\right)$-vector of observations on $k_{1}$ explanatory variables for firm $i, \beta_{1}$ is a $\left(k_{1} \mathrm{x} 1\right)$ vector with corresponding regression coefficients and $\varepsilon_{i}$ is a normally distributed error term with constant variance.

The standard Tobit model ignores the fact that not all violations committed by firms are detected by the regulators, i.e. violations are only partially observed. Following Poirier (1980), Feinstein (1990) and others, we add one equation modeling the probability that a firm's violations are detected. We let the binary variable $D_{i}$ indicate whether violations are detected: $D_{i}=1$ if one or more violations are detected; and $D_{i}=0$ otherwise. Violations are only observed when a firm intends to violate the rules $\left(F_{i}^{*}>0\right)$ and violations are detected $\left(D_{i}=1\right): F_{i}=F^{*}{ }_{i} D_{i}$ when $F_{i}^{*}>0$ and $D_{i}=1$; and $F_{i}=0$ otherwise. The resulting model is called a Tobit model with partial observability:

(2) $D_{i}^{*}=X_{2 i} \beta_{2}+u_{i}$

$$
\begin{array}{ll}
D_{i}=1, & \text { if } D_{i}^{*}>0, \\
D_{i}=0, & \text { if } D_{i}^{*} \leq 0,
\end{array}
$$

(3) $F_{i}^{*}=X_{1 i} \beta_{1}+\varepsilon_{i}$

$$
\begin{array}{ll}
F_{i}=D_{i} F^{*}{ }_{i}, & \text { if } F^{*}{ }_{i}>0 \text { and } D_{i}=1, \\
F_{i}=0, & \text { if otherwise. }
\end{array}
$$

where $X_{2 i}$ is a $\left(1 \times k_{2}\right)$-vector of observations on $k_{2}$ explanatory variables for firm $i$ that help predict detection of violations, $\beta_{2}$ is a $\left(k_{2} \times 1\right)$ vector containing the corresponding regression coefficients and $u_{i}$ is a random error term. 
We use a probit model for the probability of detection in Equation (2). Estimation results for binary-choice models are usually not very sensitive to the choice of the distribution, e.g. a probit or logit specification. A less innocuous assumption is the normal distribution of the error term $\varepsilon_{i}$ in the Tobit equations (1) and (3). As the dependent variable in our study is derived from a count of violations and violations occur infrequently, the residuals are unlikely to follow a normal distribution. We use the Lagrange-Multiplier (LM) test of Chesher and Irish (1987) to test the normality assumption, using generalized residuals.

As the normality assumption of the Tobit model turns out to be frequently violated in practice, and is not easily corrected due to nature of the dependent variable, we also estimate count data models as an alternative. Even though the dependent variable, the average number of violations per year is measured on a ratio scale, it can be transformed backed to count data with almost no loss of information. After multiplying the average number of violations per year by four, the length of the 2003-2006 period, the resulting series has only three non-integer values (i.e. $3 / 333=0.9 \%$ of the total). Rounding these three values to the nearest integer, we are left with a dependent variable that closely resemble count data (with excess zeros), as illustrated in Figure 1B.

The transformed dependent variable, denoted by $y_{i}$, can be modeled with a count data regression model, e.g. the negative binomial model (NB):

$$
P\left[Y=y_{i} \mid X_{1 i}\right]=\frac{\theta^{\theta} \lambda_{i}^{y_{i}} \Gamma\left(\theta+y_{i}\right)}{\left(\theta+\lambda_{i}\right)^{\theta+y_{i}} \Gamma(\theta) y_{i} !}, \quad \lambda_{i}=\exp \left(X_{1 i} \beta_{1}\right)
$$

where $\theta>0$ is an overdispersion parameter. The negative binomial count model is quite general and suited for data with overdispersion, when the variance of the dependent is greater than the mean. The Poisson count data model assumes that the mean and variance are equal and is a special case of the negative binomial model. A standard Likelihood Ration (LR) test can be applied to test for overdispersion. 
As count data in practice often display more zero values than positive values, a separate probit equation can be added to distinguish the data process for zero outcomes from the process for positive outcomes. As before, let the dummy variable $D_{i}$ denotes whether violations are detected or not. A count model data for $y_{i}$ with partial observability is then defined as follows:

(5) $D_{i}^{*}=X_{2 i} \beta_{2}+u_{i}$

$$
\begin{array}{ll}
D_{i}=1, & \text { if } D_{i}^{*}>0, \\
D_{i}=0, & \text { if } D^{*} \leq 0,
\end{array}
$$

(6) $P\left[Y=0 \mid X_{1 i}\right]=\phi \frac{\theta^{\theta}}{\left(\theta+\lambda_{i}\right)^{\theta}}+(1-\phi)$,

$$
P\left[Y=y_{i} \mid X_{1 i}\right]=\phi \frac{\theta^{\theta} \lambda_{i}^{y_{i}} \Gamma\left(\theta+y_{i}\right)}{\left(\theta+\lambda_{i}\right)^{\theta+y_{i}} \Gamma(\theta) y_{i} !}, \text { for } y_{i}>0
$$

with $\phi=P\left[D_{i}=1\right]=P\left[D^{*}{ }_{i}>0\right]$ denoting the probability of detection.

Model (5)-(6) is called a zero-inflated negative binomial model in the econometric literature (ZINB). Within the context of our research, it is simply a negative binomial regression model with an additional equation to take into account partial observability of violations.

For comparing the fit of two models with and without partial observability, e.g. Tobit versus Tobit with partial observability, or NB versus ZINB, a standard Wald or LR test cannot be applied, as the models are non-nested. Instead, as suggested by Greene (2003), we use Voung's statistic (Vuong, 1989). Let $f_{1}\left(y_{i} \mid x_{i}\right)$ and $f_{2}\left(y_{i} \mid x_{i}\right)$ denote the conditional probability of $y_{i}$ for two competing non-nested econometric models. Vuong's statistic $v$ is defined as follows:

(7) $v=\frac{\sqrt{n}\left(\frac{1}{n} \sum_{i=1}^{n} m_{i}\right)}{\sqrt{\frac{1}{n} \sum_{i=1}^{n}\left(m_{i}-\frac{1}{n} \sum_{i=1}^{n} m_{i}\right)^{2}}}$, with $m_{i}=\log \left(f_{1}\left(y_{i} \mid x_{i}\right) / f_{2}\left(y_{i} \mid x_{i}\right)\right)$. 
The statistic has a limiting standard normal distribution. We reject model 2 in favor of model 1 at the 5\% significance level if $v>1.96$, and we reject model 1 in favor of model 2 if $v<-1.96$. Vuong's test does not favor one model over the other for values within the range $|v| \leq 1.96$; in those cases we rely on Akaike's information criterion (AIC) instead.

\subsection{Explanatory Variables}

We will now list all explanatory variables for the regression models, including a brief motivation and the expected sign of the corresponding coefficients.

\subsubsection{Explanatory variables for the violation propensity equation $\left(X_{1 i}\right)$}

We include the overall formal good governance adoption index (CG Total) as the first explanatory variable in the violation propensity equation to test our main hypothesis, which states that formal good governance policy adoption has a non-negative relation with subsequent violations of rules and regulations.

The remaining hypotheses related to symbolic versus substantive governance are tested using interaction terms of CG Total with: (i) a dummy for state-owned firms (Government); (ii) a dummy for family-owned firms (Family); (iii) a dummy for firms with a controlling shareholder, other than the state or a family (Other); (iv) a dummy variable for early adoption (EarlyAdopt); (v) a dummy variable for "talk-only" firms (TalkOnly); (vi) the logarithm of total assets (LnAssets); and (vii) return on assets (ROA).

Further, we include the debt-to-assets ratio as an explanatory variable in the fraud propensity equation, as firms with high levels of debt might pay more attention to maintaining good relations with large creditors (mainly banks in Thailand) than shareholders. Compliance with exchange listing rules might have lower priority for firms with higher levels of debt financing, leading to more violations. Furthermore, Dechow et al. (1996) point out that highlyleveraged firms are more likely to misstate financial statements and manipulate earnings to avoid debt-covenant violations. 


\subsubsection{Explanatory variables for the violation detection equation $\left(X_{2 i}\right)$}

We now describe the variables we expect to be related to the detection of violations and are included in the fraud detection equation of the models with partial observability. Please note that in regular Tobit and NB models (i.e. without partial observability) these variables are included in the fraud propensity equation to avoid potential missing variable problems and to facilitate comparison among models with and without partial observability.

The first variable we select for the fraud detection equation is past violations, measured by the average number of violations per year listed in the period 1990-2002. As observed by Dana (2001), regulators and auditors closely monitor firms with repeated violations, so the probability of apprehension may increase with past violations.

The second variable we select is a dummy indicating return on assets (ROA) in 2002 is in the top or bottom percentile. As noted by Loebbecke et al. (1989), if a company has been experiencing high profit, management may be motivated to misstate the financial statements during a subsequent downturn to maintain the appearance of high profitability. Likewise, for lowprofit firms, Loebbecke et al. (1989) found that poor financial performance often causes management to place undue emphasis on reported earnings. Experienced regulators and auditors might therefore scrutinize firms with either very low or high profitability more closely.

The third variable we use in the fraud detection equation is size, measured by the logarithm of total assets (LnAsset). Larger firms are often followed more closely by investors and other outsiders than smaller firms. On the other hand, large firms might be more difficult to monitor due to their increased complexity. Further, small firms may have fewer resources to invest in implementation of good governance practices, and auditors and regulators might as a result scrutinize small firms more closely. Which of these opposing effects dominates is left to be revealed by the data. Please note that in models where size is also included as an interaction term 
with $C G$ Total to test hypothesis $\mathrm{H} 7 \mathrm{~b}$, we drop size as a stand-alone explanatory variable to avoid serious identification and multicollinearity problems (the correlation is $98 \%) .{ }^{14}$

\section{Results}

This section discusses our empirical results. First, we show descriptive statistics of the data and discuss correlations between the main variables. Then we present regression results and check the robustness of the results across model specifications

\subsection{Summary Statistics and Correlations}

Table 2 presents summary statistics of the formal good governance policy adoption index and the three subindices. The composite index (CG Total) has a mean of 69.77 with standard deviation 14.20, and ranges from 28.59 to 96.05 . As a preliminary analysis, we look at the correlation between the code adoption index and violations. CG Total in 2002 and the average frequency of violations in the period 2003-2006 have a correlation of -0.24 with a t-statistic of -4.52 (not shown in the table), which indicates a statistically significant negative relationship.

Further, in Table 3 we group the firms into five quantiles by $C G$ Total and estimate the mean frequency of violations within each group. It is clear that the average frequency of violations is monotonically decreasing as the group average of CG Total increases. The ANOVA F-test and Welch F-test clearly reject equality of the mean violation frequency among the quintile groups (with p-values of 0.002 and 0.000 , respectively).

The inverse relationship reported suggests that firms with higher formal good governance policy adoption scores indeed behave better than firms with poorer scores, implying substantive implementation of governance policies. However, we cannot readily make the above conclusion since here we have not controlled for other factors that might affect violation propensity and the violation detection probability. We will investigate the relationship in a fully specified model

\footnotetext{
${ }^{14}$ Except for the extremely high correlation between LnAsset and the interaction term LnAsset*CG Total, all other correlations among the explanatory variables are modest (i.e. multicollinearity is not a problem).
} 
in Subsection 6.3. Table 4 shows the explanatory variables—as well as their summary statisticsthat will be used in the empirical models.

\subsection{Results regarding Formal Good Governance Policy Adoption}

To test the first part of hypotheses 2, 3, 4, and 7 (H2a, H3a, H4a, H7a, respectively), we run an

OLS regression of the formal good governance policy adoption index CG Total on a dummy for state-owned firms, a dummy for non-state-owned firm with a controlling shareholder, return on assets (proxy for firm performance) and the log of total assets (proxy for firm size). We also regress each of the three governance sub-indices on the explanatory variables for comparison. Table 5 reports the OLS results.

We find that firm size is always positively related to $C G$ Total, while past performance does not affect the adoption of formal corporate governance policies by firms. These results support our hypothesis H7a, stating that large firms are more likely to adopt good governance policies, due to economies of scale and increased institutional attention. The results are not in line with hypothesis $\mathrm{H} 4 \mathrm{a}$, predicting that boards of poorly performing firms react by adopting more formal good governance policies. Concentrated ownership and lack of pressure by outsiders might explain why this result of Westphal and Zajac (1994) is not supported among our sample of Thai firms.

The government as a controlling shareholder does not seem to affect the adoption of corporate governance policies, contrasting with what we expected in $\mathrm{H} 2 \mathrm{a}$. This may be partly due to the small number of state-owned firms in the sample ( $7 \%$ of the sample firms). The presence of other types of controlling shareholders (mainly family business groups, followed by domestic institutions) is negatively related to the overall index, a result that appears to be driven by a significantly negative relation with the Board Structure and Independence sub-index (CG Board). We conclude that widely held firms adopt formal good governance policies more readily than firms with a controlling shareholder, rejecting H3a. The reason may be that Thai firms with 
controlling shareholders have a lower need for formal good governance policies, since controlling shareholders have sufficient influence on management to secure themselves against expropriation. Further, improving minority shareholder rights, and the firm's "governance image" in general, might perhaps not be a high priority for Thai firms with a controlling shareholder (compared to the sample of U.S. firms investigated by Westphal and Zajac, 1994, 2001). ${ }^{15}$

\subsection{Governance Policy Adoption and Violations of Governance Rules}

We now test the main hypotheses regarding factors that affect the extent to which formal good governance policy adoption predicts subsequent violations of rules and regulations. Table 6 displays the baseline Tobit estimation results.

Consistent with the correlation results, after controlling for other factors in a fully specified model, $C G$ Total in 2002 has a significant negative relation with subsequent violations in the period 2003-2006, suggesting that Thai firms on average substantively implement good governance policies. For a widely-held firm of average size and profitability, a one standard deviation increase in CG Total is associated with a decrease in the propensity to commit violations of 0.20 per year ( $32 \%$ decrease relative to the mean) and a decrease in the probability of committing violations from $22 \%$ to $15 \%$. Thus, our hypothesis $\mathrm{H} 1$ is rejected.

Now we turn to the interaction terms between $C G$ Total and other variables, to test our remaining hypotheses. The coefficients for CGTotal $* Z \_L n A s s e t$ and CGTotal $* Z \_R O A$ are negative and significant, suggesting that governance implementation is less substantive at larger firms and less profitable firms. This provides evidence supporting hypotheses H4b and H7b. ${ }^{16}$ As

\footnotetext{
${ }^{15}$ Consistent with the above finding, Ananchotikul (2007) also finds that foreign ownership is usually negatively correlated with the corporate governance quality of Thai firms. She views that foreign controlling shareholders are not different from domestic controlling shareholders in that they both favor weak corporate governance because it allows them to exploit minority shareholders.

${ }^{16}$ Please note that the significant negative coefficient for CG Total $* Z_{-}$LnAsset implies that among large firms, firms with higher governance adoption scores have a lower frequency of detected violations. An alternative explanation for this empirical finding is that large firms have more political power and are better able to lobby the regulators not to state publicly that they have violated the rules. A corresponding alternative interpretation for the negative interaction between size and CG Total, and higher governance
} 
expected, the relation between $C G$ Total and violations is significantly less negative among "talk only" firms. Interestingly, the overall relation between $C G$ Total and violations is still negative for "talk only" firms, suggesting that even within this group adoption of good governance policy is not purely symbolic. ${ }^{17}$ Governance implementation is just less substantive among "talk only" firms, compared to other firms. Our hypothesis H6 is supported.

Considering the rest of the interaction terms, the results show that early adoption and ownership variables do not play a role affecting the relationship between $C G$ Total and violations. Thus, $\mathrm{H} 2 \mathrm{~b}, \mathrm{H} 3 \mathrm{~b}$, and $\mathrm{H} 5$ are rejected. The fact that the hypothesis regarding early adopters is rejected subscribes the main finding that policy and practice are not completely decoupled, as late adopters do not appear to be trend followers who adopt policies only symbolically. Perhaps late adopters were previously uninformed about the benefits of good governance and willing to make necessary changes to their governance structure once they gained more understanding. Further, we find that firms with controlling owners do not appear to implement good governance policies more or less substantively than widely-held firms. Again, this supports the main finding, as firms with controlling owners do have greater opportunities to engage in symbolic governance.

Focusing on the remaining explanatory variables, we find the coefficient of the debt-toassets ratio and the past violations variable are positive and significant at $1 \%$ level. Not surprisingly, firms with a large debt burden and firms with bad past records of violations have a higher rate of violations in the subsequent period. Firm size, proxied by log of total assets, is a negative predictor or violations, i.e. large firms on average violate the rules less often than small firms. Firms with extremely poor and extremely high performance (proxied by the dummy for high- and low-profit) are associated with more violations, as expected.

policy adoption among large firms is as follows: large firms with the ability to influence regulators adopt good governance policy more readily than smaller firms, but only symbolically; among large firms a higher $C G$ Total score reflects stronger influence on regulators, leading to lower number of detected violations. We thank Barry Eichengreen for pointing out this alternative interpretation.

${ }^{17}$ The sum of the coefficients for $C G$ Total and CG Total * TalkOnly is -0.007881 , with a p-value of 0.08 (based on a Wald test for the sum of the coefficients). 


\subsection{Robustness of the Results}

As discussed in the econometric models section, we also estimate a Tobit with partial observability, to cope with the partially-observed nature of violations. Table 7 presents the estimations results. The signs and significance of the coefficients for the explanatory variables almost always remain unchanged compared to the results for the regular Tobit models. For robustness sake, a count-data negative binomial model (NB) and a zero-inflated negative binomial model (ZINB) are also estimated to deal with the non-normality of the dependent variable and check if the Tobit results are robust (see Table 8). Again, the main results carry over from the previous models.

Focusing on model fit, we find that the regular Tobit model and the NB model cannot be rejected by Vuong's test in favor of extended models taking into account partial observability. Akaike's Information Criterion (AIC) - lower AIC indicates a better fit - favors the models without partial observability. Finally, as expected, the normality assumption of the Tobit models appears to be seriously violated: the p-value of the normality test is 0.000 across all Tobit models. Thus, the negative binomial model may be preferred based on model specification tests and the AIC.

As a further robustness check, we have also used the average severity-weighted number of violations as the dependent variable, based on the classification of violations in three severity groups in Table 1 . The results are very similar to those for the non-weighted case and not reported to save space (available on request).

Finally, in all the above regressions we have taken corporate governance policy adoption as exogenous. One might worry that firms did not adopt corporate governance reforms randomly, and that there are unobservables that explain both adoption and detected violations, giving rise to the problems of endogeneity and omitted variables. For example, firms that have recently violated some of the governance rules — creating a disreputable image for themselves — might have a hard time seeking for qualified and honest outsiders to serve on the Board of Directors. They might 
also be occupied with consequent enforcement procedures, so that they have fewer resources left for improving corporate governance policies, leading to lower governance scores. As another example, firm size might be a factor that affects both governance policy adoption and detected violations. Suppose that large firms have more political power and ability to lobby the regulators not to announce that they have violated listing rules or engaged in fraudulent practices. If large firms rationally anticipate their ability to influence regulators and value an external image of "good governance", they could decide to adopt good governance policies purely symbolically, while subduing detection of violations through lobbying. Thus, firm size might potentially be a factor that affects both corporate governance policy adoption and detected violations. ${ }^{18}$

We use an instrumental variable approach to address the potential endogeneity problem. Our instrument for corporate governance practice is a dummy indicating the presence of at least one large block (1 percent of total shares or larger) of foreign institutional shareholdings. This variable is significantly positively correlated with $C G$ Total (correlation $=0.20, \mathrm{p}$-value $=0.000$ ). Regarding its validity as an instrument, we believe that this dummy variable is exogenous with respect to violations: since the majority of Thai firms (more than 70 percent) have a controlling shareholder with at least 25 percent blockholding, a one percent shareholding by a foreign institution is relatively small and should not be sufficient to affect, positively or negatively, violations and regulatory actions.

Two-stage model results are presented in Table 9. In the first stage, we estimate an OLS regression of CG Total on the same control variables as in Table 5 and an additional dummy for the presence of a large foreign institutional shareholder as an instrument. The second stage looks at the impact of $C G$ Total (using fitted values from the first stage) on violations, controlling for other variables as in the full model of Table 6 . We find that the sign and significance of most

\footnotetext{
${ }^{18}$ Please note that it is not obvious whether firm size is a good instrument for influence on regulators, as family ties, political connections and ethnic background might also play an important role. This is an interesting area for further research. We thank Barry Eichengreen for his comments on a potential endogeneity problem.
} 
determinants in the second stage are preserved (i.e. same as our main Tobit and NB results), except that $C G$ Total has a positive sign and is no longer significant. Based on this two-stage model result, if our instrument was truly valid, then we would have to conclude that the adoption of corporate governance policies is not related to subsequent violations; that is, Thai firms typically implement good governance policies symbolically. Nonetheless, even in a two-stage model setting, the relation is still significantly less negative among firms with poor prior performance, smaller firms and among "talk only" firms, confirming that these firms implement the policies less substantively than other firms.

We include the two-stage model estimation results in the robustness section rather than in the main discussion of results because there is an argument for, and evidence of, randomness or exogeneity of firm-level corporate governance in emerging markets. The overall R-squared of the first stage regression is only $10 \%$, indicating that the independent variables cannot explain corporate governance policy adoption well. This is in line with Doidge, Karolyi and Stulz (2004) who reason that, when financial development is poor, the incentives to improve firm-level governance are low because outside finance is expensive and the adoption of better governance mechanisms is costly. Doidge et al. (2004) show that firm characteristics explain almost none of the variation in firm-level governance ratings in less developed countries. Hence, the insignificant coefficient of CG Total in our second stage regression might as well occur due to a lack of explanatory power and valid instruments in the first stage regression.

Further, in an emerging market like Thailand one would expect "lobbying power" to be more closely associated with the powerful business families who dominate the economy than a general proxy like firm size. However, family ownership is not related significantly to the number of detected violations, nor associated with higher levels of governance policy adoption, seemingly contradicting the "lobbying power" explanation for the two-stage regression results. Regardless, in our opinion endogeneity and omitted variables problems are very important issues that deserve more thorough investigation once timeseries data and better instruments become available. 


\section{Conclusions}

This paper investigates whether the adoption of formal good corporate governance policies by listed firms is mainly symbolic or indicative of substantive implementation of good governance practices. We use data on Thai listed firms to test whether firms with higher levels of good governance policy adoption are less likely to violate official rules and regulations put in place to protect shareholders. We construct a formal corporate governance policy adoption index, using data collected by the Stock Exchange of Thailand in 2002. We use violations of listing rules and securities laws by firms in the period 2003-2006 as an outcome-based measure of substantive implementation of good governance practices.

Our empirical results suggest that Thai firms on average implement governance policies substantively, as opposed to symbolically: a higher level of adoption of formal good governance policies is associated with a significantly lower number of subsequent violations in the period 2003-2006. However, the strength of the relationship between policy adoption and violations is weaker among smaller firms and less profitable firms, but still negative nonetheless. Lack of resources might explain why smaller and less profitable firms implement good governance policies less substantively than other firms. Further, the relation is weaker among "talk-only" firms that excel in issuing declarations on governance and business ethics, while lagging in adoption of policies related to shareholder rights and board independence.

We find that the presence of a controlling owner does not significantly affect the relation between policy adoption and subsequent violations. The fact that firms with powerful controlling shareholders do not appear to engage in symbolic adoption of governance policies is interesting. Lack of outside pressure to adopt governance reforms might be a valid explanation: in Thailand there is no active market for corporate control and there are no powerful domestic institutional investors pressing for governance reforms. In the absence of pressure by outsiders, taking into account that $77 \%$ of Thai firms have one or more controlling shareholders, if a firm voluntarily 
decides to adopt formal good governance policies it might simply reflects the firm's genuine intent to substantively implement good governance practices.

Our results provide a new perspective on the results of Westphal and Zajac (1994, 2001). They argue that powerful CEO's might choose symbolic adoption to gain reputational benefits, while avoiding the potential costs of these policies by not implementing them substantively. Westphal and Zajac $(1994,2001)$ provide empirical evidence of such decoupling of policy and practice using data on long term incentive plans and share repurchase plans adopted by large U.S. firms. The majority of large listed U.S. firms are widely-held and monitored continuously by institutional investors and hedge funds for potential weaknesses in governance and management performance. Hence, both executives and directors in the U.S. need to worry about their image among outsiders. Thai firms, on the other hand, typically have one or more controlling shareholders and face little to no pressure from active minority investors. That might explain our finding of limited symbolic action among Thai firms. Put very simply: why would firms stage a play if there is no (relevant) audience?

An alternative explanation for the empirical findings in our paper is that one or more unobserved factors are affecting both good governance policy adoption and detected violations, potentially leading to a spurious relation between policy adoption and violations. For example, suppose that large firms have more political influence and can lobby the regulators not to disclose their violations; further, if large firms anticipate their influence on regulators, they could decide to adopt good governance policies to a larger extent than other firms, but purely symbolically. Two-stage instrumental variable regressions provide support for this alternative explanation. Unfortunately, the results are hampered by a lack of good instruments for governance policy adoption and lack of systematic variation in policy adoption among firms $\left(\mathrm{R}^{2}=0.10\right)$. Further, in an emerging market like Thailand one would expect "lobbying power" to be more closely associated with the powerful business families who dominate the economy than a general proxy like firm size. Family ownership is not related significantly to the number of detected violations. 
Regardless, endogeneity and omitted variables problems are very important issues that deserve more thorough investigation once timeseries data and better instruments become available.

Our paper can be extended in several directions. First, we lack timeseries information on governance code adoption for running a panel regression that might provide more reliable results, in case endogeneity and omitted variables problems exist, as indicated above. Second, if a database of comparable information on governance adoption and fraud and violations can be constructed for multiple countries - and this is still an open question, due to potential divergence in rules and regulations from one country to the other, as well as variety in the levels of enforcement - it would be very interesting to extend this study to multiple countries.

\section{References}

Agrawal, A., Chadha, S., 2005. Corporate governance and accounting scandals. Journal of Law and Economics 48, 371-406.

Ananchotikul, N., 2007. Does foreign investment really improve corporate governance? Evidence from Thailand. Unpublished manuscript, University of California, Berkeley.

Beasley, M.S., 1996. An empirical analysis of the relation between the board of director composition and financial statement fraud. Accounting Review 71, 443-465.

Black, B.S., Jang, H., Kim, W., 2006. Does corporate governance predict firms' market values? Evidence from Korea. Journal of Law, Economics, and Organization 22, 366-413

Chen, G., Firth, M., Gao, D.N., Rui, O.M., 2006. Ownership structure, corporate governance, and fraud: Evidence from China. Journal of Corporate Finance 12, 424-448.

Chesher, A., Irish, M., 1987. Residual analysis in the grouped data and censored normal linear model. Journal of Econometrics 34, 33-62.

Christmann, P., Taylor, G., 2006. Firm self-regulation through international certifiable standards: Determinants of symbolic versus substantive implementation. Journal of International Business Studies 37, 863-878.

Dana, D.A., 2001. Rethinking the puzzle of escalating penalties for repeat offenders. Yale Law Journal 110, 733-783.

Dechow, P.M., Sloan, R.G., Sweeney, A.P., 1996. Causes and consequences of earnings manipulation: An analysis of firms subject to enforcement actions by the SEC. Contemporary Accounting Research 13, 1-36. 
Doidge, C.A., Karolyi, G.A., Stulz, R.M., 2004. Why do countries matter so much for corporate governance? Working Paper, European Corporate Governance Institute.

Durnev, A., Kim, E.H., 2005. To steal or not to steal: Firm attributes, legal environment, and valuation. Journal of Finance 60, 1461-1493.

Feinstein, J., 1990. Detection controlled estimation. Journal of Law and Economics 33, 233-276.

Greene, W. H., 2003. Econometric analysis. Prentice Hall, Upper Saddle River, NJ.

Klapper, L.F., Love, I., 2004. Corporate governance, investor protection, and performance in emerging markets. Journal of Corporate Finance 10, 703-728.

Loebbecke, K.J., Eining, M.M., Willingham, J., 1989. Auditors' experience with material irregularities: frequency, nature, and detectability. Auditing: A Journal of Practice and Theory 9, 1-28.

Netter, J.M., Mitchell, M.L., 1989. Stock-repurchase announcements and insider transactions after the October 1987 stock market crash. Financial Management 18, 84-96.

Park, Y.W., Shin, H.H., 2004. Board composition and earnings management in Canada. Journal of Corporate Finance 10, 431-457.

Poirier, D. J., 1980. Partial observability in bivariate probit models. Journal of Econometrics 12, 209-217.

Stevens, J.M, Steensma, H.K., Harrison, D.A., Cochran, P.L., 2005. Symbolic or substantive document? The influence of ethics codes on financial executives' decisions. Strategic Management Journal 26, 181-195.

Uzun, H., Szewczyk, S.H., Varma, R., 2004. Board composition and corporate fraud. Financial Analysts Journal 60, 33-43.

Voung, Q.H., 1989. Likelihood ratio tests for model selection and non-nested hypothesis. Econometrica 57, 307-333.

Westphal, J.D., Zajac, E.J., 1994. Substance and symbolism in CEO's long-term incentive plans. Administrative Science Quarterly 39, 367-390.

Westphal, J.D., Zajac, E.J., 1998, The symbolic management of stockholders: Corporate governance reforms and shareholder reactions. Administrative Science Quarterly 43, 127-153.

Westphal, J.D., Zajac, E.J., 2001. Decoupling policy from practice: The case of stock repurchase programs. Administrative Science Quarterly 46, 202-228.

Yeung, G., Mok, V., 2005. What are the impacts of implementing ISOs on the competitiveness of manufacturing industry in China? Journal of World Business 40, 139-157. 
Table 1: Violations of SET / SEC Rules, 1990-2006

\begin{tabular}{|c|c|c|c|c|c|c|}
\hline Violation & $\begin{array}{l}\text { Number of } \\
\text { Violations: } \\
\text { 1990-2006 }\end{array}$ & $\begin{array}{l}\text { Violations } \\
\text { per Year: } \\
\text { 1990-2002 }\end{array}$ & $\begin{array}{l}\text { Violations } \\
\text { per Year: } \\
\text { 2003-2006 }\end{array}$ & Source & $\begin{array}{l}\text { Level of } \\
\text { Severity* }\end{array}$ & Description of Violation \\
\hline \multicolumn{7}{|l|}{$\underline{\text { Fraud }}$} \\
\hline Expropriation & 8 & 2.00 & 0.00 & SEC & 1 & Expropriation of assets by managers of the firm. \\
\hline Falsification & 5 & 1.25 & 0.00 & SEC & 1 & Management falsified financial statements or other documents. \\
\hline Insider Trading & 2 & 0.50 & 0.00 & SEC & 1 & $\begin{array}{l}\text { Managers or owners of the firm used inside information to trade } \\
\text { the firm's shares for their own benefit. }\end{array}$ \\
\hline Market Manipulation & 7 & 1.75 & 0.25 & SEC & 1 & $\begin{array}{l}\text { Managers or owners of the firm manipulated the trading of } \\
\text { company's stocks to mislead or lure others to buy or to sell. }\end{array}$ \\
\hline \multicolumn{7}{|l|}{ Financial Statements Not Correct } \\
\hline Accounting Violation & 1 & 0.00 & 0.25 & SET & 1 & $\begin{array}{l}\text { Financial statements failed to comply with Generally Accepted } \\
\text { Accounting Standards. }\end{array}$ \\
\hline Financial Statement Amendment & 10 & 0.00 & 2.50 & SET & 1 & Company was required to amend their financial statements. \\
\hline Adverse Opinion & 50 & 0.00 & 12.50 & SET & 1 & $\begin{array}{l}\text { Auditors issued an adverse opinion the on firm's financial } \\
\text { statement. }\end{array}$ \\
\hline Disclaimer of Opinion & 38 & 0.00 & 9.50 & SET & 2 & $\begin{array}{l}\text { Auditors issued a disclaimer of opinion on the firm's financial } \\
\text { statement. }\end{array}$ \\
\hline Qualified Opinion & 2 & 0.00 & 0.50 & SET & 2 & $\begin{array}{l}\text { Auditors issued a qualified opinion on the firm's financial } \\
\text { statement. }\end{array}$ \\
\hline Financial Statement Rectification & 1 & 0.08 & 0.00 & SET & 3 & $\begin{array}{l}\text { Company was asked by the SET to rectify mistakes in their } \\
\text { financial statement. }\end{array}$ \\
\hline
\end{tabular}

* 1 = Severe violation, 2 = Medium violation, 3 = Minor violation. 
Table 1: Violations of SET / SEC Rules, 1990-2006 (continued)

\begin{tabular}{llllll}
\hline & Number of & Violations & Violations & & Level of \\
Violation & Violations: & per Year: & per Year: & Source & Severity* \\
& $1990-2006$ & $1990-2002$ & $2003-2006$ & & Description of Violation \\
\hline
\end{tabular}

\section{Failure to Disclose Information}

Connected Party Transaction

$\begin{array}{lllll}3 & 0.08 & 0.50 & \text { SET } & 1 \\ 185 & 12.69 & 5.00 & \text { SET } & 1 \\ 24 & 1.38 & 1.50 & \text { SET } & 2\end{array}$

Failure to Submit Financial Statements according to the Procedure

Information Deadline

129

6.85

10.00

Information Procedure, \#1

20.38

11.50

Information Procedure, \#2

10

0.08

2.25

Information Procedure, \#3

15

1.08

0.25

0.08

0.25

Tender offer

2

Reporting of share holdings

0.00

0.25

Takeover Information

10

0.23

1.75
SET

SET

SET

SET

SET/

SEC

SEC

SET
Company failed to, and hence was forced to; disclose a connected party transaction by the SET.

Company failed to, and hence was forced to; disclose material information to the public by the SET.

2 Company submitted incomplete and/or unclear information, and the SET summoned the company to submit complete information.

* 1 = Severe violation, 2 = Medium violation, 3 = Minor violation. 
Table 2: Corporate Governance Policy Adoption Indices, 2002

\begin{tabular}{llccccc}
\hline \multicolumn{1}{c}{ Index } & Name & Obs & Mean & Std. Dev. & Min & Max \\
\hline & & & & & & \\
Governance policy statements subindex & CG Policy & 333 & 58.54 & 29.35 & 0.00 & 100.00 \\
Board structure and independence policy subindex & CG Board & 333 & 77.64 & 11.57 & 36.11 & 100.00 \\
Shareholder rights policy subindex & CG Shareholders & 333 & 72.74 & 9.95 & 21.90 & 95.48 \\
& & & & & & \\
Overall good governance policy adoption index & CG Total & 333 & 69.77 & 14.20 & 28.59 & 96.05 \\
\hline
\end{tabular}

Table 3: Average Frequency of Violations, by Quintile of CG Total, 2003-2006

\begin{tabular}{ccccc}
\hline \multirow{2}{*}{ Quintile of CG index } & Obs. & Mean CG index & \multicolumn{2}{c}{$\begin{array}{c}\text { Frequency of violations } \\
\text { (per firm per year listed) }\end{array}$} \\
\cline { 4 - 5 } & & & Mean & Std. Dev. \\
\hline 1st & 66 & 46.75 & 0.33 & 0.59 \\
2nd & 67 & 65.37 & 0.20 & 0.39 \\
3rd & 67 & 71.55 & 0.19 & 0.51 \\
4th & 66 & 78.11 & 0.13 & 0.30 \\
5th & 67 & 86.86 & 0.04 & 0.15 \\
& & & & 0.43 \\
\hline
\end{tabular}

Test for equality of means of the violation frequency grouped by CG index quintile

\begin{tabular}{lccc}
\hline \multicolumn{1}{c}{ Method } & df & Value & Probability \\
\hline \hline Anova F-test & $(4,328)$ & 4.229774 & 0.0024 \\
Welch F-test* & $(4,151.50)$ & 6.3975 & 0.0001 \\
& & & \\
\hline *Test allows for unequal cell variances
\end{tabular}

*Test allows for unequal cell variances 
Table 4: Definition and Descriptive Statistics of Explanatory Variables

\begin{tabular}{|c|c|c|c|c|c|c|}
\hline Variable & Definition & Obs. & Mean & Std. Dev. & Min & $\operatorname{Max}$ \\
\hline LnAsset & Natural logarithm of total assets & 333 & 8.0 & 1.6 & 3.5 & 14.0 \\
\hline ROA & Return on assets, winsorized at the $1 \%$ and $99 \%$ percentile (left and right tail) & 332 & 6.9 & 9.2 & -28.5 & 29.1 \\
\hline DebtAsset & Total debt to assets ratio, winsorized at the $99 \%$ percentile (right tail only) & 333 & 52.2 & 31.1 & 0.4 & 175.7 \\
\hline EarlyAdopt & $\begin{array}{l}\text { Dummy: } 1 \text { for firms that in } 2000 \text { had an independent director ratio of at least } \\
25 \% \text { and separated the positions for Chairman and CEO; } 0 \text { otherwise. }\end{array}$ & 333 & 0.11 & 0.31 & 0 & 1 \\
\hline TalkOnly & $\begin{array}{l}\text { Dummy: } 1 \text { for firms with } C G \text { Policy among the top } 33 \% \text {, but either } C G \\
\text { Shareholders or CG Board among the bottom } 33 \% \text {. }\end{array}$ & 333 & 0.13 & 0.34 & 0 & 1 \\
\hline High/low profit & $\begin{array}{l}\text { Dummy: } 1 \text { for high- and low-proft firms, i.e. firms in either the top or bottom } \\
10 \% \text { percentile based on ROA; } 0 \text { otherwise. }\end{array}$ & 332 & 0.20 & 0.40 & 0 & 1 \\
\hline Controlling & $\begin{array}{l}\text { Dummy: } 1 \text { for firms with at least one controlling shareholder with } 25 \% \text { or larger } \\
\text { block (any type); } 0 \text { otherwise. }\end{array}$ & 333 & 0.77 & 0.42 & 0 & 1 \\
\hline Family & $\begin{array}{l}\text { Dummy: } 1 \text { for firms with a family, or family business group, as the largest } \\
\text { controlling shareholder, holding a block of } 25 \% \text { or more; } 0 \text { otherwise. }\end{array}$ & 333 & 0.50 & 0.50 & 0 & 1 \\
\hline Government & $\begin{array}{l}\text { Dummy: } 1 \text { for firms with the governmentas the largest controlling shareholder, } \\
\text { holding a block of } 25 \% \text { or more; } 0 \text { otherwise. }\end{array}$ & 333 & 0.07 & 0.26 & 0 & 1 \\
\hline Other & $\begin{array}{l}\text { Dummy: } 1 \text { for firms where the largest controlling shareholder holding a block of } \\
\text { at least } 25 \% \text { is neither the government nor a family; } 0 \text { otherwise. }\end{array}$ & 333 & 0.20 & 0.40 & 0 & 1 \\
\hline Violtot02 & Average number of violations per year listed, in the period 1990-2002. & 318 & 0.18 & 0.22 & 0.00 & 2.40 \\
\hline Violtot06 & Average number of violations per year listed, in the period 2003-2006. & 333 & 0.18 & 0.43 & 0.00 & 2.50 \\
\hline
\end{tabular}

Notes: For variable Violtot02, we code as missing observations of firms that were listed for less than 6 months during the $1990-2002$ period. 
Table 5: OLS Regressions for Formal Good Governance Policy Adoption Scores

\begin{tabular}{lcccc}
\hline \multirow{2}{*}{ Independent variable } & \multicolumn{4}{c}{ Dependent variable } \\
\cline { 2 - 5 } & CG Total & CG Policy & CG Board & CG Shareholders \\
\hline \multirow{2}{*}{ Constant } & $72.49^{* * *}$ & $61.68^{* * *}$ & $81.45^{* * *}$ & $72.61^{* * *}$ \\
& $(0.000)$ & $(0.000)$ & $(0.000)$ & $(0.000)$ \\
LnAsset & $3.138^{* * *}$ & $4.796^{* * *}$ & $2.077^{* * *}$ & $2.495^{* * *}$ \\
& $(0.000)$ & $(0.001)$ & $(0.000)$ & $(0.000)$ \\
ROA & 1.052 & 1.841 & 0.865 & 0.108 \\
& $(0.168)$ & $(0.259)$ & $(0.145)$ & $(0.813)$ \\
Government & 0.035 & -1.192 & -0.151 & 2.452 \\
& $(0.990)$ & $(0.837)$ & $(0.959)$ & $(0.258)$ \\
Non-government controlling & $-3.922^{* *}$ & -4.365 & $-5.487 * * *$ & -0.053 \\
shareholder dummy & $(0.022)$ & $(0.240)$ & $(0.000)$ & $(0.971)$ \\
& & & & \\
\hline Observations & 332 & 332 & 332 & 332 \\
R-squared & 0.08 & 0.04 & 0.09 & 0.08 \\
F(4, 327) & 8.54 & 3.90 & 10.43 & 5.35 \\
\hline P-Var)
\end{tabular}

p-values from robust estimations in parentheses.

$*, * *, * * *$ significant at $10 \%, 5 \%$ and $1 \%$ level, respectively.

Note: Non-government controlling shareholder dummy has a value of 1 if there exists a controlling shareholder (with $25 \%$ block or larger) other than the government; 0 otherwise. 
Table 6: Explaining Violations -- Tobit Model Estimation Results

Dependent variable: Average number of violations per year listed, 2003-2006

\begin{tabular}{|c|c|c|c|c|}
\hline \multirow{2}{*}{ Independent variable } & \multicolumn{4}{|c|}{ Tobit } \\
\hline & (1) & (2) & (3) & (4) \\
\hline \multirow[t]{2}{*}{ Constant } & 0.656 & $0.721 *$ & $0.080 *$ & -0.340 \\
\hline & $(0.119)$ & $(0.094)$ & $(0.080)$ & $(0.336)$ \\
\hline \multirow[t]{2}{*}{ Debt to assets } & $0.011 * * *$ & $0.012 * * *$ & $0.012 * * *$ & $0.010 * * *$ \\
\hline & $(0.000)$ & $(0.000)$ & $(0.000)$ & $(0.000)$ \\
\hline \multirow[t]{2}{*}{ CG Total } & $-0.009 * *$ & $-0.012 * *$ & $-0.011 * *$ & $-0.014 * * *$ \\
\hline & $(0.046)$ & $(0.010)$ & $(0.026)$ & $(0.004)$ \\
\hline \multirow[t]{2}{*}{ CG Total * TalkOnly } & --- & $0.005 * *$ & $0.006^{* *}$ & $0.013 * *$ \\
\hline & & $(0.024)$ & $(0.020)$ & $(0.013)$ \\
\hline \multirow[t]{2}{*}{ CG Total * EarlyAdopt } & --- & 0.001 & 0.002 & 0.002 \\
\hline & & $(0.738)$ & $(0.582)$ & $(0.570)$ \\
\hline \multirow[t]{2}{*}{ CG Total * Family } & --- & --- & -0.003 & -0.002 \\
\hline & & & $(0.195)$ & $(0.512)$ \\
\hline \multirow[t]{2}{*}{ CG Total $*$ Government } & --- & --- & -0.002 & -0.001 \\
\hline & & & $(0.556)$ & $(0.872)$ \\
\hline \multirow[t]{2}{*}{ CG Total * Other } & --- & --- & 0.000 & 0.001 \\
\hline & & & $(0.965)$ & $(0.774)$ \\
\hline \multirow[t]{2}{*}{ CG Total * LnAsset } & --- & --- & --- & $-0.004 * * *$ \\
\hline & & & & $(0.001)$ \\
\hline \multirow[t]{2}{*}{$C G$ Total $*$ ROA } & --- & --- & --- & $-0.002 * *$ \\
\hline & & & & $(0.013)$ \\
\hline \multirow[t]{2}{*}{ Average previous violations, $1990-2002$} & $1.007 * * *$ & $1.015 * * *$ & $1.003 * * *$ & $0.862 * * *$ \\
\hline & $(0.000)$ & $(0.000)$ & $(0.000)$ & $(0.000)$ \\
\hline \multirow[t]{2}{*}{ Dummy for high-and low-profit firms } & $0.292 * *$ & $0.302 * *$ & $0.308 * *$ & $0.245^{*}$ \\
\hline & $(0.048)$ & $(0.040)$ & $(0.037)$ & $(0.097)$ \\
\hline \multirow[t]{2}{*}{ LnAsset } & $-0.180 * * *$ & $-0.169 * *$ & $-0.174 * * *$ & --- \\
\hline & $(0.000)$ & $(0.001)$ & $(0.000)$ & \\
\hline Sigma & 0.831 & 0.822 & 0.818 & 0.790 \\
\hline \multicolumn{5}{|l|}{ Tests: } \\
\hline Akaike information criterion (AIC) & 1.272 & 1.268 & 1.278 & 1.260 \\
\hline Log-likelihood & -194.663 & -191.939 & -190.615 & -186.682 \\
\hline Normality test & 88.255 & 82.436 & 92.824 & 86.251 \\
\hline p-value & $(0.000)$ & $(0.000)$ & $(0.000)$ & $(0.000)$ \\
\hline
\end{tabular}

p-values from in parentheses.

$*, * *, * * *$ significant at $10 \%, 5 \%$ and $1 \%$ level, respectively.

Note: LnAsset and ROA are standardized, i.e. z-scores. 
Table 7: Explaining Violations -- Tobit Models with Partial Observability

Dependent variable: Average number of violations per year listed, 2003-2006

\begin{tabular}{|c|c|c|c|c|}
\hline \multirow{2}{*}{ Independent variable } & \multicolumn{4}{|c|}{ Tobit with partial observability } \\
\hline & (1) & $(2)$ & (3) & (4) \\
\hline \multicolumn{5}{|l|}{ Fraud Propensity Equation: } \\
\hline Constant & $\begin{array}{c}-0.069 \\
(0.866)\end{array}$ & $\begin{array}{c}0.007 \\
(0.875)\end{array}$ & $\begin{array}{c}0.084 \\
(0.849)\end{array}$ & $\begin{array}{c}0.215 \\
(0.612)\end{array}$ \\
\hline Debt to assets & $\begin{array}{c}0.011 * * * \\
(0.000)\end{array}$ & $\begin{array}{c}0.012 * * * \\
(0.000)\end{array}$ & $\begin{array}{c}0.012 * * * \\
(0.000)\end{array}$ & $\begin{array}{c}0.009 * * * \\
(0.000)\end{array}$ \\
\hline CG Total & $\begin{array}{c}-0.011 * * \\
(0.042)\end{array}$ & $\begin{array}{c}-0.014 * * \\
(0.020)\end{array}$ & $\begin{array}{l}-0.012^{*} \\
(0.056)\end{array}$ & $\begin{array}{c}-0.016^{* * * *} \\
(0.006)\end{array}$ \\
\hline CG Total $*$ TalkOnly & --- & $\begin{array}{c}0.005 \\
(0.102)\end{array}$ & $\begin{array}{l}0.005^{*} \\
(0.070)\end{array}$ & $\begin{array}{l}0.007 * * \\
(0.014)\end{array}$ \\
\hline CG Total * EarlyAdopt & --- & $\begin{array}{c}0.001 \\
(0.873)\end{array}$ & $\begin{array}{c}0.001 \\
(0.688)\end{array}$ & $\begin{array}{c}0.001 \\
(0.762)\end{array}$ \\
\hline CG Total * Family & --- & --- & $\begin{array}{l}-0.004 * \\
(0.092)\end{array}$ & $\begin{array}{l}-0.001 \\
(0.624)\end{array}$ \\
\hline CG Total $*$ Government & --- & --- & $\begin{array}{c}-0.004 \\
(0.519)\end{array}$ & $\begin{array}{c}0.000 \\
(0.948)\end{array}$ \\
\hline CG Total $*$ Other & --- & --- & $\begin{array}{c}-0.001 \\
(0.669)\end{array}$ & $\begin{array}{c}0.001 \\
(0.790)\end{array}$ \\
\hline CG Total $*$ LnAsset & --- & --- & --- & $\begin{array}{c}-0.004 * * * \\
(0.005)\end{array}$ \\
\hline CG Total $*$ ROA & --- & --- & --- & $\begin{array}{c}-0.003^{* *} \\
(0.001) \\
\end{array}$ \\
\hline Sigma & 0.822 & 0.806 & 0.806 & 0.774 \\
\hline \multicolumn{5}{|l|}{ Fraud Detection Equation: } \\
\hline Constant & $\begin{array}{l}4.527 * * \\
(0.025)\end{array}$ & $\begin{array}{l}4.546^{* *} \\
(0.028)\end{array}$ & $\begin{array}{l}4.338 * * \\
(0.027)\end{array}$ & $\begin{array}{c}0.011 \\
(0.978)\end{array}$ \\
\hline Average previous violations, $1990-2002$ & $\begin{array}{l}3.979 * * \\
(0.065)\end{array}$ & $\begin{array}{l}3.933 * * \\
(0.073)\end{array}$ & $\begin{array}{l}3.753 * * \\
(0.071)\end{array}$ & $\begin{array}{c}4.754 \\
(0.212)\end{array}$ \\
\hline Dummy for high-and low-profit firms & $\begin{array}{c}0.532 \\
(0.484)\end{array}$ & $\begin{array}{c}0.510 \\
(0.509)\end{array}$ & $\begin{array}{c}0.613 \\
(0.458)\end{array}$ & $\begin{array}{c}1.381 \\
(0.406)\end{array}$ \\
\hline LnAsset & $\begin{array}{c}-0.573^{* *} \\
(0.013) \\
\end{array}$ & $\begin{array}{c}-0.570^{* *} \\
(0.016) \\
\end{array}$ & $\begin{array}{c}-0.548^{* *} \\
(0.015) \\
\end{array}$ & --- \\
\hline \multicolumn{5}{|l|}{ Tests: } \\
\hline 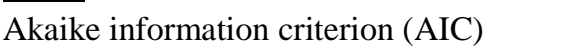 & 1.323 & 1.325 & 1.333 & 1.298 \\
\hline Log-likelihood & -201.743 & -200.019 & -198.249 & -191.681 \\
\hline $\begin{array}{l}\text { Normality test } \\
p \text {-value }\end{array}$ & $\begin{array}{l}126.636 \\
(0.000)\end{array}$ & $\begin{array}{l}124.559 \\
(0.000)\end{array}$ & $\begin{array}{l}109.802 \\
(0.000)\end{array}$ & $\begin{array}{l}95.136 \\
(0.000)\end{array}$ \\
\hline $\begin{array}{l}\text { Vuong test: Tobit vs. partial observability } \\
\text { p-value }\end{array}$ & $\begin{array}{c}1.328 \\
(0.184)\end{array}$ & $\begin{array}{c}1.475 \\
(0.140)\end{array}$ & $\begin{array}{c}1.532 \\
(0.126)\end{array}$ & $\begin{array}{c}1.603 \\
(0.109)\end{array}$ \\
\hline
\end{tabular}

p-values in parentheses.

$*, * *, * * *$ significant at $10 \%, 5 \%$ and $1 \%$ level, respectively. 
Table 8: Explaining Violations -- Count-Data Models

Dependent variable: Round( 4 x Average number of violations per year listed, 2003-2006)

\begin{tabular}{|c|c|c|}
\hline \multirow{2}{*}{ Independent variable } & \multicolumn{2}{|c|}{ Count-data model } \\
\hline & NB & ZINB \\
\hline \multicolumn{3}{|l|}{ Fraud Propensity Equation: } \\
\hline \multirow[t]{2}{*}{ Constant } & -0.708 & 0.276 \\
\hline & $(0.318)$ & $(0.692)$ \\
\hline \multirow[t]{2}{*}{ Debt to assets } & $0.017 * * *$ & $0.015 * * *$ \\
\hline & $(0.000)$ & $(0.000)$ \\
\hline \multirow[t]{2}{*}{ CG Total } & $-0.022 * *$ & $-0.025 * * *$ \\
\hline & $(0.018)$ & $(0.007)$ \\
\hline \multirow[t]{2}{*}{ CG Total * TalkOnly } & $0.011 * *$ & $0.012 * *$ \\
\hline & $(0.012)$ & $(0.010)$ \\
\hline \multirow[t]{2}{*}{ CG Total * EarlyAdopt } & 0.003 & 0.000 \\
\hline & $(0.639)$ & $(0.932)$ \\
\hline \multirow[t]{2}{*}{ CG Total * Family } & -0.002 & -0.001 \\
\hline & $(0.695)$ & $(0.776)$ \\
\hline \multirow[t]{2}{*}{ CG Total * Government } & -0.006 & 0.003 \\
\hline & $(0.534)$ & $(0.568)$ \\
\hline \multirow[t]{2}{*}{ CG Total * Other } & 0.004 & -0.006 \\
\hline & $(0.481)$ & $(0.564)$ \\
\hline \multirow[t]{2}{*}{ CG Total * LnAsset } & $-0.007 * * *$ & $-0.007 * * *$ \\
\hline & $(0.001)$ & $(0.004)$ \\
\hline \multirow[t]{2}{*}{$C G$ Total * ROA } & $-0.005 * *$ & $-0.006 * * *$ \\
\hline & $(0.016)$ & $(0.000)$ \\
\hline \multirow[t]{2}{*}{ Average previous violations, $1990-2002$} & $1.500 * * *$ & --- \\
\hline & $(0.004)$ & \\
\hline \multirow[t]{2}{*}{ Dummy for high-and low-profit firms } & 0.221 & --- \\
\hline & $(0.445)$ & \\
\hline LnAsset & --- & --- \\
\hline Theta (overdispersion parameter) & 1.616 & 1.295 \\
\hline \multicolumn{3}{|l|}{ Fraud Detection Equation: } \\
\hline \multirow[t]{2}{*}{$\overline{\text { Constant }}$} & --- & -0.059 \\
\hline & & $(0.864)$ \\
\hline \multirow[t]{2}{*}{ Average previous violations, $1990-2002$} & --- & 4.878 \\
\hline & & $(0.117)$ \\
\hline \multirow[t]{2}{*}{ Dummy for high-and low-profit firms } & --- & 1.918 \\
\hline & & $(0.595)$ \\
\hline LnAsset & --- & --- \\
\hline \multicolumn{3}{|l|}{ Tests: } \\
\hline 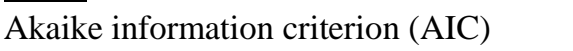 & 1.910 & 1.925 \\
\hline Log-likelihood & -289.723 & -291.176 \\
\hline Vuong test: NB vs. ZINB & \multirow{2}{*}{\multicolumn{2}{|c|}{$\begin{array}{c}0.175 \\
(0.861)\end{array}$}} \\
\hline p-value & & \\
\hline
\end{tabular}

p-values from robust estimations in parentheses.

$*, * *, * * *$ significant at $10 \%, 5 \%$ and $1 \%$ level, respectively.

Note: $\mathrm{NB}=$ Negative binomial model, ZINB = Zero-inflated negative binomial model 
Table 9: Explaining Violations - Two-Stage Model

\begin{tabular}{|c|c|c|c|}
\hline \multicolumn{2}{|l|}{ First stage } & \multicolumn{2}{|l|}{ Second stage } \\
\hline \multirow{2}{*}{ Independent variable } & \multirow{2}{*}{$\begin{array}{c}\text { OLS } \\
C G \text { Total }\end{array}$} & \multirow{2}{*}{ Independent variable } & NB \\
\hline & & & Average violations \\
\hline \multirow[t]{2}{*}{ Constant } & $70.213 * * *$ & \multirow[t]{2}{*}{ Constant } & -4.606 \\
\hline & $(0.000)$ & & $(0.268)$ \\
\hline \multirow{2}{*}{$\begin{array}{l}\text { Dummy for large foreign } \\
\text { institutional block }\end{array}$} & $4.139 * *$ & \multirow[t]{2}{*}{ Debt to assets } & $0.019 * * *$ \\
\hline & $(0.014)$ & & $(0.000)$ \\
\hline \multirow[t]{2}{*}{ LnAsset } & $2.310 * * *$ & \multirow[t]{2}{*}{ CG Total (fitted) } & 0.030 \\
\hline & $(0.003)$ & & $(0.599)$ \\
\hline \multirow[t]{2}{*}{$R O A$} & 0.984 & \multirow[t]{2}{*}{ CG Total * TalkOnly } & $0.009 *$ \\
\hline & $(0.195)$ & & $(0.076)$ \\
\hline \multirow[t]{2}{*}{ Government } & 1.430 & \multirow[t]{2}{*}{ CG Total * EarlyAdopt } & 0.004 \\
\hline & $(0.646)$ & & $(0.476)$ \\
\hline \multirow{15}{*}{$\begin{array}{l}\text { Non-government controlling } \\
\text { shareholder dummy (Other) }\end{array}$} & $-3.796 * *$ & \multirow[t]{2}{*}{ CG Total * Family } & 0.003 \\
\hline & $(0.027)$ & & $(0.644)$ \\
\hline & & \multirow[t]{2}{*}{ CG Total * Government } & -0.007 \\
\hline & & & $(0.474)$ \\
\hline & & \multirow[t]{2}{*}{ CG Total * Other } & 0.007 \\
\hline & & & $(0.256)$ \\
\hline & & \multirow[t]{2}{*}{ CG Total $*$ LnAsset } & $-0.010 * *$ \\
\hline & & & $(0.008)$ \\
\hline & & \multirow[t]{2}{*}{$C G$ Total * ROA } & $-0.005^{* *}$ \\
\hline & & & $(0.014)$ \\
\hline & & \multirow{4}{*}{$\begin{array}{l}\text { Average previous violations, } \\
\text { 1990-2002 } \\
\text { Dummy for high- and low-profit firms }\end{array}$} & $1.708 * *$ \\
\hline & & & 0.001 \\
\hline & & & 0.248 \\
\hline & & & $(0.399)$ \\
\hline & & Theta (overdispersion parameter) & 1.686 \\
\hline Observations & 332 & Observations & 317 \\
\hline R-squared & 0.10 & Pseudo R-squared & 0.132 \\
\hline $\mathrm{F}(5,326)$ & 7.98 & Log-likelihood & -291.774 \\
\hline
\end{tabular}

p-values in parentheses.

$*, * *, * * *$ significant at $10 \%, 5 \%$ and $1 \%$ level, respectively.

Note: CG Total in the second stage is the fitted value of CG Total from the first stage regression. 


\section{Figure 1}

\section{Panel A}

Histogram: Average violations per year lised, 2003-2006

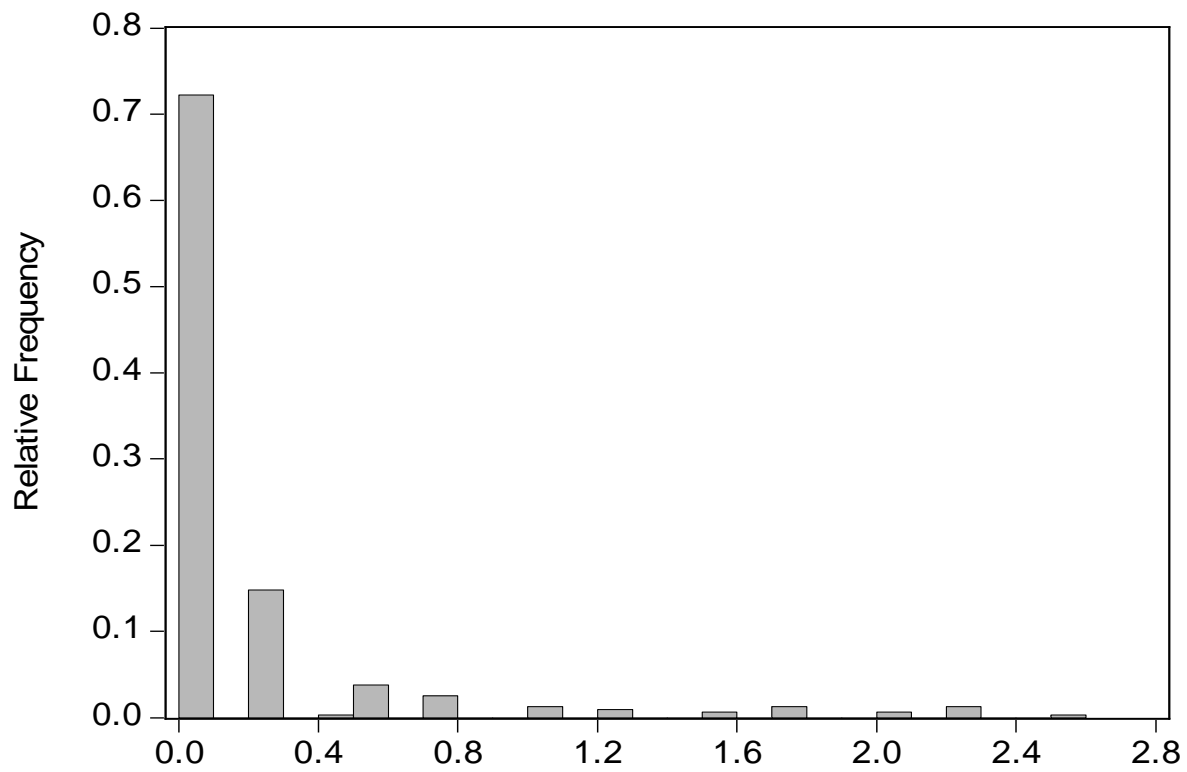

Panel B

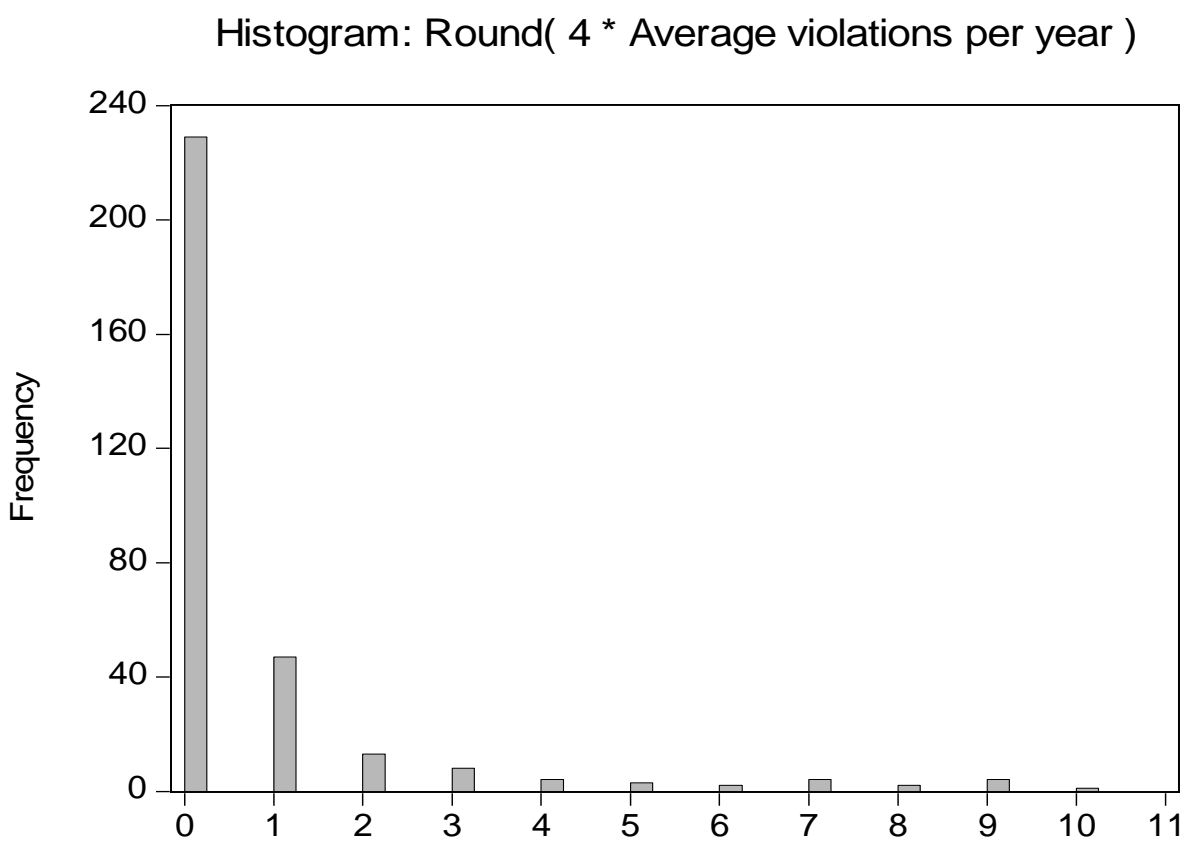




\section{Appendix A: Good Governance Principles from the Thai Code Not Used for Measuring Formal Policy Adoption}

\section{A. Principles with sub-scores partially based on substantive implementation}

The sub-score for the following principles might have some substantive aspects that overlap with our SET and SEC violations data:

Principle 3: "Rights of Various Groups of Stakeholders"

- The sub-score for this principle is based on accusation/prosecution concerning violation of stakeholders' legal rights.

Principle 6: "Conflicts of Interest"

- Sufficient measures are in place to prevent the use of inside information.

- No connected transactions took place, or directors/audit committee are of the opinion that the price/condition is equivalent to transactions with third party.

Principle 15: "Investor Relations"

- Information disclosure complies with the rules and regulations.

- There is an investor relations unit or staff.

B. Principles with sub-scores measuring only information disclosure:

We do not use the sub-scores for the two principles listed below, as they do not contain information about adoption of formal governance policies that could be decoupled from practice (firms either disclose the information or not).

Principle 10: "Directors and Management Remuneration"

- The company provides detailed information on the remuneration of Board members and management.

Principle 11: "Board of Directors' Meetings"

- Each director's attendance record is disclosed in the company's annual report.

\section{Principle deemed not relevant for good governance:}

Finally, we do not use the following principle, as it does not consider the relation between the firm and its various stakeholders, but rather internal risk management procedures.

Principle 13: "System of Control and Internal Auditing" 